\title{
Uluslararası Dergilerde Yayımlanan Türkiye Adresli Makalelerin Atıf Etkisini Artıran Faktörler
}

\section{Factors Increasing the Citation Impact of Papers from Turkey Published in International Journals}

\author{
Yaşar Tonta* ${ }^{*}$ ve Müge Akbulut ${ }^{* *}$
}

$\ddot{\boldsymbol{z}}$

Amaç: Bu araştırmanın amacı Türkiye (TR) adresli uluslararası makalelerin atıf sayısını artıran faktörleri ortaya çıkarmaktır. Yöntem: 2006-2015 yıllarında yayımlanan yaklaşık 226 bin TR adresli makaleye ait bibliyografik veriler indirilmiş, bu verilerden olasılı̆̆a dayalı tabakalı \%2'lik bir örneklem seçilmiş ve örneklemde yer alan makalelere ilişkin atıf sayısı, dergi etki faktörü, dergilerin çeyreklik değerleri, ortak yazar sayısı vb. gibi ilgili bilgiler çeşitli kaynaklardan elde edilmiştir. Daha sonra; makale, dergi, işbirliği, dizinleme, destek ve erişimle ilgili 19 bağımsız değişken saptanarak bu değişkenlerin TR adresli makalelerin atıf sayısı üzerindeki etkisi engel modeli (hurdle model) kullantlarak analiz edilmiştir. Bulgular: TR adresli makalelerin atıf sayısını artıran ve hiç atıf almayan makale sayısını azaltan en önemli faktörler, makalelerin yayımlandı̆̆ dergilerin beş yıllık dergi etki faktörü ve çeyreklik (Q1) değerleri ile makalelerin kaynakçalarında yer alan referans sayılarıdır. Yabancı ülkelerle işbirliği yapılarak yayımlanan makalelerin atıf sayısı daha yüksektir. Makalelerin konusu, desteklenip desteklenmemesi ve makaleye erişim yönteminin (açık/kapalı erişim) atıf sayısı üzerinde olumlu etkisi yoktur. Sonuç: Bu bulgular Türkiye adresli makalelerin bilimsel etkisini artırmak için dergi etki faktörü yüksek dergilerde yayımlanmasını özendiren, ama etki faktörü düşük dergilerde yayın yapılmasının da önüne geçen akademik yükseltme ve teşvik politikalarının geliştirilmesi gerektiğini göstermektedir. Özgünlük: Bu araştırma, engel modelini kullanarak makale, dergi, işbirliği, dizinleme, destek ve erişimle ilgili çok sayıda faktörün TR adresli makalelere yapılan atıf sayısına doğrudan etkisini araştıran ilk çalışmadır.

Anahtar Sözcükler: Atıf etkisi; dergi etki faktörü; akademik teşvik; engel modeli.

\footnotetext{
* Hacettepe Üniversitesi, Bilgi ve Belge Yönetimi Bölümü, Ankara, Türkiye. E-posta: yasartonta@ gmail.com Hacettepe University, Department of Information Management, Ankara, Turkey.E-mail: yasartonta@gmail.com ** Ankara Yıldırım Beyazıt Üniversitesi, Bilgi ve Belge Yönetimi Bölümü, Ankara, Türkiye. E-posta: mugeakbulut@gmail.com Ankara Yıldırım Beyazıt University, Department of Information Management, Ankara, Turkey. E-mail: mugeakbulut@gmail.com
}

Geliş Tarihi - Received: 05.05.2021

Kabul Tarihi - Accepted: 22.09.2021

Yayımlanma Tarihi - Published: 30.09.2021 


\section{Abstract}

Objective: This paper aims to find out the factors that are likely to increase the citation impact of Turkey-addressed international papers. Method: For this purpose, we downloaded bibliographic records of some 226,000 TR-addressed papers that were published between 2006 and 2015, therefrom selected a sample (2\%) using stratified probabilistic sampling technique, and obtained relevant data from various sources such as the number of citations and coauthors, journal impact factors (JIF) and journal quartiles pertaining to each paper in the sample. We then identified 19 independent variables on article, journal, cooperation, support and access levels and analyzed the data using the hurdle model. Findings: The strongest factors increasing the number of citations of TR-addressed papers are five-year JIFs and journal quartiles (Q1) in which TR-addressed papers appeared and the number of references in papers' reference lists. These factors also reduce the number of papers with zero citations. Papers published in cooperation with other countries collect higher numbers of citations. Factors such as the subjects of papers, whether papers received monetary support or not, and methods by which papers can be accessed (open or closed access) have no impact on the number of citations received. Implications: Findings indicate that academic promotion and support policies encouraging publishing in high impact journals while forestalling publishing in low impact journals should be developed in order to increase the scientific impact of TR-addressed papers. Originality: This is the first study using hurdle model to investigate the direct impact of several article, journal, collaboration, monetary support and access level explanatory variables on the number of citations that TR-addressed papers receive.

Keywords: Citation impact; journal citation impact; academic incentives; hurdle model.

\section{Giriş}

Bilimsel yayınlara yapılan atıf sayısı bir yayının bilimsel, entellektüel, ekonomik ve toplumsal etkisini ölçmek için kullanılan en önemli ölçütlerden birisidir. Bir ülkenin bilimsel yayınlarına yapılan ortalama atıf sayısı o ülkenin bilimsel zenginliğinin bir göstergesi olarak yorumlanmaktadır. Uzun demokratik geçmişi olan, küçük ve iyi yönetilen ülkeler ekonomik zenginliklerini bilimsel zenginliğe daha etkili bir biçimde dönüştürmektedir (Allik, Lauk ve Realo, 2020, s. 364-365). Özellikle bilimsel dergilerde yayımlanan makalelere yapılan atıf sayısına dayanan dergi etki faktörü, makale etki puanı, $h$ dizini gibi ölçevler (metrics) birer "kalite göstergesi”" olarak kabul edilip tek tek yayınların, araştırmacıların ve araştırma kurumlarının başarısını ölçmek için de kullanılmaktadır.

Oysaki kalite göstergesi olarak kullanılan dergi etki faktörü değerleri bilim dallarına göre değişmektedir. Çünkü fen bilimleri, tıp, sosyal bilimler gibi alanlarda bilimsel iletişim için farklı yayın mecraları (kitap, dergi makalesi, bildiri vd.) tercih edilmekte, araştırmacı ve yayın sayıları ve bu yayınlara yapılan atıf sayıları ile araştırmacıların atıf yapma davranışları alan, dergi, yazar, makale vb. gibi etmenlere göre büyük değişiklik göstermektedir (Bornmann ve Daniel, 2008; Good, Vermeulen, Tiefenthaler ve Arnold, 2015; Kostoff, 1998; Lindsey, 1989; MacRoberts ve MacRoberts, 1989, 1996, 2018; Sivertsen, 2016, 2019). Yaklaşık 60 yıldır atıfların bağlamı, atıf yapılan kaynakların içeriği, araştırmacıların atıf yapma/yapmama nedenleri üzerine çok sayıda araştırma yapılmıştır. Atıf Türleri Ontolojisinde; destekleme, 
eleştirme, yerme, düzeltme vb. gibi yaklaşık 100 farklı atıf türü listelenmektedir. Ama uygulamada, yayınlara yapılan bütün atıflar genelde olumlu atıflar olarak değerlendirilmektedir (Bornmann ve Daniel, 2008, s. 50; CiTO, 2018).

Konuyla ilgili çeşitli araştırmalarda ve bildirgelerde dergi etki faktörünün ve atıf analizine dayalı nicel göstergelerin araştırma değerlendirme amacıyla tek başına kullanılmaması önerilmiş olsa da bu tür uygulamalar halen devam etmektedir (Hicks, Wouters, Waltman, de Rijcke ve Rafols, 2015; San Francisco Declaration, 2012; Seglen, 1997). Bunun önemli nedenlerinden biri, günümüzde hemen hemen her sektörde giderek artan her şeyi "sayma ve ölçme tutkusu"dur (Muller, 2019). Öte yandan Web of Science (WoS) ve Scopus gibi bibliyografik veri tabanlarına, özellikle dergilerde yayımlanan makalelere ilişkin atıf verilerine ve buna dayanan ölçevlere kolayca erişilebilmesi, bilimsel etkinin sayılmasını ve ölçülmesini kolaylaştırmıştır. Örneğin, WoS'ta 21 binin üzerinde bilimsel dergi, 120 bin civarında kitap dizinlenmektedir. İlgili veri tabanında bu yayınlara ait 80 milyon civarında bibliyografik kayıt, 1,6 milyar atıf verisi, 12 bin derginin atıf sayısı, dergi etki faktörü ve makale etki puanı gibi etki ölçümlerinde yaygınlıkla kullanılan bibliyometrik veriler bulunmaktadır (Pranckute, 2021, s. 27).

Atıf analizine dayanan değerlendirmeler ve sıralamalar Türkiye'de de kullanılmaktadır. Atıf sayıları gerek ülke içindeki yayınların/araştırmacıların/üniversitelerin performansını değerlendirmek gerekse uluslararası literatürde yayımlanan Türkiye adresli yayınların etkisini ölçmek ve Türkiye'nin performansını diğer ülkelerinkiyle karşılaştırmak için kullanılmaktadır.

Atıf sayısına dayalı araştırmalardan elde edilen bulgular ne yazık ki çok cesaret verici değildir. Türkiye'de neredeyse 30 yıldır uluslararası bilimsel dergilerde yayın yapılması teşvik edilmesine ve 2000 y1lından itibaren akademik atama ve yükseltmelerde "indeksli" dergilerde makale yayımlamış olma ölçütü getirilmiş olmasına karşın, bilimsel gelişmeyi tetiklemek için konulan bu tür ölçütler ve verilen teşvikler Türkiye (TR) adresli uluslararası bilimsel yayınların giderek etki değeri daha düşük dergilerde yayımlanmasına, daha az atıf almasına ve hiç atıf almayan yayın sayılarının artmasına yol açmıştır (Akçiğit ve Özcan-Tok, 2020, s. 13, 70, 76; Tonta, 2017, 2018; Tonta ve Akbulut, 2020; Yurtsever, Gülgöz, Yedekçioğlu ve Tonta, 2001, 2002, s. 74-75). Nitekim 1997-2016 yıllarında WoS'ta dizinlenen dergilerin ortalama etki faktörü 20 yılda yüzde yüz artarak 2,2'ye yükseldiği halde (Fischer ve Steiger, 2018, s. 28), aynı dönemde TR adresli makalelerin yayımlandığı uluslararası dergilerin ortalama etki faktörü 1,6' da kalmıştır. TR adresli yayınlara yapılan atıfların çoğunun bilimsel açıdan henüz yeterince gelişmemiş ülkeler tarafından yayımlanan makalelerden geldiğini de not etmekte yarar vardır (Akçiğit ve Özcan-Tok, 2020, s. 14, 28-29). Türkiye, 2008-2018 yılları arasında Scopus’ta dizinlenen TR adresli makalelere yapılan ortalama atıf sayısı ile en yüksek atıf alan ve Essential Science Indicators'ta (ESI) üst \%1'lik dilime giren makale yüzdesinin bileşiminden oluşan Yüksek Kalite Bilim Endeksinde (HQSI: High Quality Science Index) 97 ülke arasında 94. sıradadır (Allik, Lauk ve Realo, 2020, s. 376). Aynı araştırmada bir ülkenin bilimsel zenginliğiyle o ülke araştırmacılarının yayımladıkları makalelere hiç atıf yapılmaması arasında da bir ilişki kurulmakta, bilimsel zenginlik açısından daha düşük düzeydeki ülkelerin araştırmacılarının hiç atıf yapılmayan makale yayımlamalarının daha muhtemel olduğu ileri sürülmektedir (Allik, Lauk ve Realo, 2020, s. 368). 
$\mathrm{Bu}$ araştırmanın temel amacı TR adresli makalelerin atıf sayısını artıran ve hiç atıf almayan makalelerin sayısını azaltan makale, dergi, işbirliği, dizinleme, destek ve erişim düzeyleriyle ilgili faktörleri ortaya çıkarmaktır. Bu amaçla; 2006-2015 yıllarında yayımlanan ve WoS'ta dizinlenen yaklaşık 226 bin TR adresli makaleden olasılığa dayalı tabakalı bir örneklem seçilmiş ve bu makalelerin özellikleri (yazar sayısı, yayımlandı̆̆ı derginin etki faktörü, destekli araştırma olup olmadığı vs.) ile her makaleye 2006-2021 yılları arasında yapılan atıf sayıları kaydedilmiş ve veriler bu özelliklere göre engel modeli (hurdle model) kullanılarak analiz edilmiştir. Bulgular, TR adresli makalelerin atıf sayısını artıran ve hiç atıf almayan makale sayısını azaltan en önemli faktörlerin makalelerin yayımlandığı dergilerin beş yıllık etki faktörü ile çeyreklik (Q1) değerleri ve makalelerin referans listelerindeki kaynak sayıları olduğunu göstermektedir. Atıf sayısını artıran bir diğer faktör de işbirliğidir. Bu araştırmanın bulgularının araştırmacılara ve atıf sayılarına dayalı performans değerlendirmesi yapan üniversiteler ile Yükseköğretim Kurulu (YÖK) ve TÜBİTAK gibi kurumlara araştırma değerlendirme politikası geliştirmede ya da mevcut politikaları gözden geçirmede yararlı olabileceği kanısındayız.

$\mathrm{Bu}$ araştırma, toplam 19 faktörün TR adresli makalelere yapılan atıf sayısına doğrudan etkisini araştıran bildiğimiz kadarıyla ilk çalışmadır. Aşağıda önce konuyla ilgili literatür değerlendirilmekte, ardından araştırma sorusu, araştırmada kullanılan veri kaynakları, bağımlı ve bağımsız değişkenler ile verileri analiz etmek ve yorumlamak için kullanılan araştırma yöntemi açıklanmaktadır. Daha sonra ise araştırmadan elde edilen bulgular sunularak yorumlanmakta ve sonuçlar özetlenmektedir.

\section{Literatür Değerlendirmesi}

Bilimsel yayınlara atıf yapma davranışının kuramsal dayanağı iki farklı yaklaşıma göre yorumlanmaktadır. Normatif yaklaşıma göre araştırmacılar, diğer yayınlara atıf yaparak hem atıf yaptıkları yayınların kendi çalışmalarına entellektüel ve bilişsel (cognitive) katkısını kayda geçirmiş hem de bu yayınların yazarlarına kredi vermiş olurlar. Bu bakımdan bilgi aktarımında ve bilginin artmasında rol oynayan atıflara dayalı bibliyometrik analizler, bilimsel yayınları değerlendirmede ve bu yayınların etkisini ölçmede kullanılabilir. Toplumsal yapısalcı (social constructivist) yaklaşıma göre ise makalelerin bilim topluluğu tarafindan kabul görmesinde bilişsel içeriklerinin etkisi azdır. Bilimsel bilgi toplumsal olarak inşa edilir. Bilimsel bilginin üretiminde siyasi ve mali kaynaklar ile etkili bir biçimde yazma (retorik, belagat) önemli rol oynar. Araştırmacilar sadece makalelerin entellektüel içeriği nedeniyle değil, kendi tezlerini savunmak, alanlarında isim yapmak, meslektaşlarını ikna etmek, söylemi zenginleştirmek vb. gibi çok farklı amaçlarla da diğer yayınlara atıf yapmaktadırlar (Bornmann ve Daniel, 2008, s. 48-49).

Araştırmacıların atıf yapma davranışları hem normatif hem de yapısalcı yaklaşımlara göre açıklanabilmesine karşın, yarım asrı aşkın bir süredir atıf analiziyle ilgili olarak yapılan ampirik çalışmaların sonuçlarına bakılacak olursa, normatif yaklaşım zaman içinde ağırlık kazanmıştır. Bunda atıf sayılarının tek tek makale bazında olmasa bile daha genel düzeyde akran değerlendirmesi (peer review) gibi diğer bilimsel etki değerlendirmeleriyle ilişkili olmasının da kuşkusuz önemli bir payı vardır (Bornmann ve Daniel, 2008, s. 70). Fakat atıf yapma 
davranışını sadece atıf yapılan yayınların bilimsel içeriği, bağlamı ve bu yayınların ilgili alana entellektüel ve bilişsel katkısıyla açıklamak mümkün değildir. Hatta araştırmacıların sadece \%9'u atıf yaptıkları kaynakların kendi çalışmalarına katkısını "Vazgeçilmez" (\%1) ya da "Oldukça önemli" (\%8) olarak nitelendirmişlerdir. Geri kalan \%91'i ise bu kaynakları "Sınırlı" (\%56) ya da "İkinci derecede önemli” (\%35) bulmuşlardır (Bornmann ve Daniel, 2008, s. 58$59)$.

Yayınların içeriği ya da bilimsel katkısıyla doğrudan ilgili olmayan "dışsal” faktörlerle ilgili literatür birçok çalışmada ayrıntılı olarak incelenmiştir. 1960-2005 yılları arasında yapılan yaklaşık 30 çalışmanın bulgularına göre atıf yapma davranışı; zaman, disiplin, dergi, makale, okuyucu, erişilebilirlik vb. gibi faktörlerle ilişkilidir (Bornmann ve Daniel, 2008, s. 51-63). Benzeri bir biçimde, makalelerin yayımlandığı dergilerin etki faktörü, ortak yazar sayısı, referans sayısı, makalelerin uzunluğu, araştırmaların kurumsal, ulusal ve uluslararası işbirliğine dayanması, mali destek vb. gibi atıf sayısını etkilemesi muhtemel diğer faktörler de kapsamlı bir biçimde incelenmiştir (Chen, 2012; Didegah ve Thelwall, 2013a, 2013b; Fronzetti Colladon, D’Angelo ve Gloor, 2020).

Dergi etki faktörü, atıf sayısını etkileyen en önemli göstergelerden birisidir. Dergi etki faktöründeki bir birimlik artış ortalama atıf sayısını \%16 ile \%32 oranında artırmakta, hiç atıf almayan ortalama makale sayısını ise \%39 ile \%89 oranında azaltmaktadır (Didegah ve Thelwall, 2013a, s. 865). Nanobilim/nanoteknoloji ve kimya mühendisliği alanlarında da dergi etki faktörü atıf sayısını artıran en önemli faktörlerden birisidir (Didegah ve Thelwall, 2013b; Fronzetti Colladon, D’Angelo ve Gloor, 2020). Nanobilim ve nanoteknoloji alanında dergi etki faktörünün yanı sıra referans sayısı ve işbirliği yapılan kurum sayısı da hem ortalama atıf sayısının artmasında hem de hiç atıf almayan ortalama makale sayısının azalmasında etkilidir (Didegah ve Thelwall, 2013b, s. 1062). Daha büyük ölçekli bir çalışmada arXiv'de depolanan ve daha sonra bilimsel dergilerde yayımlandığ saptanan 727 bin makalenin arXiv'deki kopyalarının aldıkları atıf sayısıyla dergilerde yayımlandıktan sonra aldıkları atıf sayısı karşılaştırılmış ve etki faktörü yüksek dergilerin daha çok atıf alan makaleleri yayımladıkları, bu dergilerin yayımlanan makalelerin atıf sayısını artırdığı görülmüştür (Traag, 2021, s. 1). Ancak atıf dağılımlarının çarpıklığından dolayı etki faktörü yüksek Nature ve Science gibi çok prestijli dergilerde yayımlanan makalelerin bile yaklaşık \%75'i bu dergilerin etki faktörü katsayısı kadar atıf almamaktadır (Larivière ve diğerleri, 2016, s. 4).

Dergi etki faktörünün yanı sıra makalelerin ortak yazar ve referans sayıları, başlık, öz (abstract) ve metin uzunlukları, işbirliği ve destek gibi bir dizi diğer faktör de atıf sayılarını etkilemektedir. Önceki çalışmalarda atıf sayısını artırdığ saptanan bu faktörler tablolar halinde listelenmiş ve tartışılmıştır (Confraria, Godinho ve Wang, 2017, s. 275; Didegah ve Thelwall, 2013b, s. 1056-1057; Onodera ve Yoshikane, 2015, s. 743-749). Birkaç örnek vermek gerekirse, yüksek etki faktörlü Lancet dergisinde yayımlanan ve en çok atıf yapılan makalelerin daha çok ortak yazarı ve referansı olup, özetleri ve tam metinleri de daha uzundur (Kostoff, 2007). Kimya mühendisliği alanında makalelerin ortak yazar sayısı arttıkça atıf sayısının da arttığı, öz uzunluğu ile atıf sayısı arasında yüksek korelasyon olduğu gözlenmiştir (Fronzetti Colladon, D’Angelo ve Gloor, 2020). Mali destek (fon) bilim, teknoloji, mühendislik, matematik ve tıp (STEMM) alanlarında yayımlanan makalelerin (ilk atıflarını almasında etkili değilse de) atıf sayısını artırmaktadır (Gök, Rigby ve Shapira, 2016; Yan, Wu ve Song, 2018). 
Didegah ve Thelwall'in (2013a, 2013b) çalışmalarında da dergi etki faktörünün yanı sıra makalelerin referans listesinde yüksek etkisi olan makalelere yer verilmesinin, toplam referans sayısı ve (uluslararası) işbirliği yapılan kurum sayısının, makalelerin öz uzunluğu ve okunabilirliğinin atıf sayılarını artırdığı ve hiç atıf almayan makale sayılarını azalttığı ortaya çıkmıştır. Pek araştırılmayan bir diğer faktör ise makalelerin referans listelerinin güncelliğidir (son beş yılda yayımlanan kaynaklara referans verilmesi). Bu faktörün makalelerin atıf sayısını artıran en güçlü faktör olduğu görülmüştür (Onodera ve Yoshikane, 2015, s. 757).

Makalelere yapılan atıf sayısını etkileyen ortak yazar, referans ya da indirme sayıları, dergilerin prestiji vb. gibi dışsal faktörler, makalelerin kavramsal ve anlamsal içeriğiyle doğrudan ilgili değildir. Oysaki makalelerin entellektüel içeriği ve anlamsal yapısıyla doğrudan ilgili "içsel faktörler" makalelere yapılan atıf sayısını tahmin etmede daha etkilidir. İçsel faktörler bir alanın yapısal değişimiyle (structural variation) ilgilidir (Chen, 2012, s. 433). Bir makalenin ilgili alandaki bilimsel gelişmelere katkısı, benzeri araştırma sorularına yanıt arayan diğer araştırma gruplarının çalışmalarıyla kurduğu yeni bağlantıların bu alanda yarattığı yapısal değişim bu tür içsel faktörlere örnek olarak verilebilir (Chen, 2012, s. 439). Örneğin, yeni yayımlanan bir makalenin belli bir alandaki literatürü oluşturan ağın farklı kümeleri arasında yarattığı yeni ilişkilerin bir ölçüsü olan küme bağlantısı (cluster linkage) katsayısı, bu makaleye yapılan atıf sayısını tahmin etmede makalenin ortak yazar sayısı ve referans sayısından sirasıyla iki ve üç kat daha güçlü bir ön göstergedir (predictor) (Chen, 2012, s. 447).

İçsel faktörlere bir başka örnek makale ve yazar ağları üzerinde gerçekleştirilen sosyal ağ analizi (merkezilik ölçüleri) ve makalelerin özleri üzerinde gerçekleştirilen anlamsal (semantic) analizlerdir (uzunluk, karmaşıklık, kullanılan kelimelerin çeşitliliği ve tekilliği vd.). Dergilerin etki faktörü ve ortak yazar sayısı kontrol değişkenleri olarak kullanıldığında, sosyal ağ analizi ve anlamsal analiz değişkenleri makaleler yayımlandıktan altı yıl sonra yüksek atıf alan makaleleri \% 79,2 doğruluk oranıyla tahmin etmeye olanak sağlamaktadır (Fronzetti Colladon, D’Angelo ve Gloor, 2020, s. 370). Ancak atıf sayısını etkileyen içsel faktörlerle ilgili olarak yapılan çalışmalar oldukça kısıtlıdır.

Türkiye'nin uluslararası yayınlarıyla ilgili olarak yapılan çalışmalarda ise daha çok TR adresli makalelerin atıf etkisinde zamanla meydana gelen düşüşlere dikkat çekilmektedir. Örneğin, yaklaşık 40 yıldır TR adresli makaleler giderek etki faktörü nispeten daha düşük dergilerde yayımlanmaktadır (Akçiğit ve Özcan-Tok, 2020; Tonta, 2017). ${ }^{1}$ TR adresli makalelerin atıf etkisi dünya ortalamasının \%40’1 civarındadır. Bu nedenle yayın sayıs1 açısından bir ara dünyada 16. sıraya kadar yükselen Türkiye'nin yeri, makale başına ortalama atıf sayısına göre çok daha aşağıdadır. Örneğin Türkiye, Avrupa Birliği ülkeleri ile karşılaştırıldığında yayın sayısı açısından 10., yayın başına düşen atıf sayısı açısından (Romanya'dan sonra) sondan ikinci (A1, 2012, s. 9), 1998-2003 yıllar1 arasinda en az 10 bin makale yayımlayan 36 ülke arasında ortalama atıf sayısına göre ise 32. sıradadır (Albarrán, Perianes-Rodrígues ve Ruiz-Castillo, 2015, s. 525). TR adresli makalelerin sadece \%1'i en çok atıf yapılan \%10'luk dilimde yer almaktadır. Türkiye, 2004-2013 yılları arasında WoS'ta dizinlenen yayınların \%1,62'sini üretmiştir. Ama en çok atıf alan \%1'lik dilimi oluşturan "elit"

\footnotetext{
${ }^{1}$ Konuyla ilgili çalışmalar için bkz. Tonta (2017, s. 17-21).
} 
makalelerde atıf yapılan makalelerin sadece \%0,38'i TR adreslidir (Bornmann, Wagner ve Leydesdorff, 2018, s. 4-5). Başka bir deyişle, TR adresli makalelerin dörtte üçünden fazlasına elit makalelerde hiç atıf yapılmamaktadır. TR adresli makalelere yapılan atıflar genellikle gelişmiş ülkelerden değil, büyük ölçüde gene kendi yayınlarından (Kamalski ve diğerleri, 2017, s. 298) ve Asya ile Arap ülkelerinden gelmektedir (Akçiğit ve Özcan-Tok, 2020, s. 14, 28-29).

Ortak yazarlı ve özellikle ABD ve Avrupa ülkeleriyle işbirliği yapılarak yayımlanan makaleler daha çok atıf almaktadır. Türkiye'de işbirliğine dayanan makalelerin toplam makale sayısına oranı son yıllarda \%28'e ulaşmıştır (Akçiğit ve Özcan-Tok, 2020, s. 56-57). Scopus veri tabanındaki 2010-2014 yıllarını kapsayan yayın ve atıf sayılarına dayanan bir çalışmada uluslararası işbirliğine dayanan TR adresli yayınların atıf etkisinin dünya ortalamasının \%46 üzerinde, ulusal ve kurumsal işbirliğine dayanan yayınların atıf etkisinin ise dünya ortalamasının \%40 altında olduğu ortaya çıkmıştır (Kamalski ve diğerleri, 2017, s. 300). 20132018 yılları arasında 10 araştırma üniversitesiyle 2019 yılı Dünya Üniversiteler Sıralamasında (THE World University Rankings) ilk sıralarda yer alan 11 vakıf üniversitesine verilen TÜBİTAK Ar-Ge ve proje desteklerinin bu üniversitelerin makalelerine yapılan atıf sayılarını artırmadığ görülmüştür (Satoğlu, Balkış ve Damar, 2021, s. 90). TÜBİTAK Türkiye Adresli Uluslararası Bilimsel Yayınları Teşvik (UBYT) Programı çerçevesinde desteklenen makalelerin ortalama atıf sayısı destek almayanlara oranla biraz daha yüksektir (Tonta ve Akbulut, 2020, s. 1627). Dergi etki faktörü yüksek Q1 dergilerinde yayımlanan TR adresli makalelerin ortalama atıf sayısı daha yüksek, bu dergilerde yayımlanan ve hiç atıf almayan makalelerin oranı ise daha düşüktür (Orbay, Karamustafaoğlu ve Miranda, 2021; Orbay, Miranda ve Orbay, 2020). Ancak dünyada makalelerin yaklaşık \%40’1 Q1 dergilerinde yayımlanırken, TR adresli makalelerde bu oran sadece \%21'dir (Tonta ve Akbulut, 2020, s. 1627).

\section{Araştırma Sorusu, Veri Kaynakları, Değişkenler ve Yöntem}

Aşağıda araştırma sorusu, veri kaynakları, bağımlı ve bağımsız değişkenler ile araştırma yöntemi ayrıntılı olarak açıklanmaktadır.

\section{Araştırma Sorusu}

$\mathrm{Bu}$ çalışmanın temel amacı Türkiye adresli makalelerin atıf etkisini artıran faktörleri ortaya çıkarmaktır. Atıf etkisi TR adresli makalelere WoS'ta dizinlenen dergilerde yayımlanan makalelerden yapılan atıf sayısıyla ölçülmektedir.

Çalışmanın temel araştırma sorusu ise:

"Türkiye adresli makalelerin makale, dergi, işbirliği, dizinleme, destek ve açık erişim düzeyi özelliklerinin (1) makalelere yapılan atıf sayısının artmasında; (2) hiç atıf almayan makale sayısının azalmasında etkisi var mıdır?"

şeklinde formüle edilmiştir. Bu özellikler aşağıda "Değişkenler" alt başlı̆̆ı altında verilmektedir. 


\section{Veri Kaynaklart}

Araştırmada kullanılan 2006-2015 yılları arasında yayımlanan ve WoS'ta dizinlenen TR adresli makalelere ilişkin atıf sayısı, dergi etki faktörü, dergi çeyreklikleri gibi veriler WoS, InCites ve Journal Citation Reports'tan (JCR) elde edilmiştir. WoS veri tabanında adres alanında "Türkiye" geçen, 2006-2015 yılları arasında yayımlanmış, yayın türü "makale" olan ve Science Citation Index Expanded (SCI), Social Science Citation Index (SSCI) ya da Arts \& Humanities Citation Index'te (AHCI) dizinlenmiş yaklaşı 226.000 makaleye ait bütün veriler 25 Şubat 2021 tarihinde indirilmiştir. Makaleler yıllara göre sıralanmış ve sıralı listeden olasılığa dayalı tabakalı örneklem seçme yöntemiyle \%2'lik bir örneklem seçilmiştir $(n=4521)$. Daha sonra örneklemdeki makalelere ilişkin dergi etki faktörü, çeyreklik değerleri vb. gibi bilgiler JCR ve InCites’tan elde edilmiştir. Çeşitli makrolar yazılarak her makalenin başlığı ve özündeki sözcük sayısı, kaynakçasındaki referans sayısı, hangi dizinde ve konu başlıkları altında dizinlendiği, desteklenip desteklenmediği ve açık erişim olup olmadığı, yazar sayısı, (varsa) ortak yazarları arasında yabancı ülke(ler)den yazar olup olmadığı ve yazarlarının çalıştıkları kurumlar örneklem verilerine eklenmiştir. Örneklemde yer alan ve TÜBİTAK UBYT Programından destek alan makaleler, TÜBİTAK'tan elde edilen ödeme verilerinden saptanarak bu bilgi de veri setine eklenmiştir. WoS'taki destek bilgisi makale yayımlanmadan önce (ex ante) alınan desteği (grant), UBYT desteği ise makale yayımlandıktan sonra (ex post) yazarların TÜBİTAK'a başvurusu sonucu alınan desteği temsil etmektedir.

\section{Değişkenler}

Hazırlanan verilerden Türkiye adresli makalelerin atıf sayısını etkilemesi muhtemel toplam 19 değişken seçilmiştir. Aşağıda ve Tablo 1'de bu değişkenler kısaca tanımlanmakta ve her değişkene ilişkin tanımlayıcı istatistikler verilmektedir.

Araştırmada analiz birimi TR adresli makalelerdir. Bu makalelere yapılan atıf sayısı bağımlı değişkendir.

Örneklemde yer alan 4521 makaleye toplam $76.380 \mathrm{kez}$ atıf yapılmıştır (min: 0, maks: 1361, $\bar{x}=17$; $s=40$ (Tablo 1). ${ }^{2}$ Makalelerin yarısı (ortanca) 2006-2021 yılları arasında yedi ve daha az sayıda, dörtte üçü (hiç atıf almayanlar da dahil) ortalamanın (17) altında atıf almıştır.

Türkiye adresli makalelerin atıf sayısını (bağımlı değişken) etkilemesi muhtemel 19 bağımsız (açıklayıcı) değişken altı grup altında sınıflandırılmıştır:

1. Makale düzeyi değişkenler: Yayın yılı, yazar sayısı, başlıktaki sözcük sayısı, özdeki sözcük sayısı ve referans sayısıdır. Bu değişkenler sırasıyla makalenin yayın yılını, ortak yazar sayısını, başlığı ve özündeki sözcük sayısını ve kaynakçasında yer alan referans sayısını göstermektedir. 2006-2015 yılları arasında TR adresli makale sayısı yaklaşık iki kat artmıştır. Makalelerin yarısının ortak yazar sayısı bir ile dört arasındadır $(\bar{x}=10 ; s=107)$. Makale başlık ve özlerindeki ortalama sözcük sayısı sırasıyla 13 ve 178 'dir. Her makalede ortalama 30 kaynağa referans verilmektedir.

\footnotetext{
${ }^{2}$ Tablo 1'de de belirtildiği gibi, aralıklı/oranlı değişkenler için $\bar{x}$ ve $s$ sırasıyla örneklem ortalamasını ve standart sapmasını göstermektedir.
} 


\section{Tablo 1}

Değişkenler, değişken tanımları ve tanımlayıcı istatistikler

\begin{tabular}{|c|c|c|}
\hline Değişken adı & Tanımlar & $\begin{array}{l}\text { Tanımlayıcı istatistikler (min, maks, ortn, } \bar{x} \text {, } \\
\text { s, kodlar, } n, \% \text { ) }\end{array}$ \\
\hline $\begin{array}{l}\text { Atıf sayısı } \\
\text { (Bağımlı değişken) }\end{array}$ & $\begin{array}{l}\text { Makaleye 2006-2021 (25 Şubat) yılları arasında } \\
\text { yapılan atıf sayısı }(76.380)\end{array}$ & $\begin{array}{l}\min =0 ; \text { maks }=1361 ; \text { ortn }=7 ; \bar{x}=17 ; s=40,11 ; \\
\text { atıf say1s1 }<\bar{x} \text { makale sayıs1: } 3367(\% 75) .\end{array}$ \\
\hline Yayın y1lı & Makalenin yayın yılı & $\begin{array}{l}\text { 2006: } 278(\% 6) ; 2007: 364(\% 8) ; 2008: 360 \\
(\% 8) ; 2009: 449(\% 10) ; 2010: 450(\% 10) ; \\
\text { 2011: } 436(\% 10) ; 2012: 504(\% 11) ; 2013: \\
536(\% 12) ; 2014: 577(\% 13) ; 2015: 567 \\
(\% 13)\end{array}$ \\
\hline Yazar sayısı & Makalenin yazar sayısı & $\min =1 ; \operatorname{maks}=2425 ;$ ortn$=4 ; \bar{x}=10 ; s=107,21$ \\
\hline $\begin{array}{l}\text { Başlıktaki sözcük } \\
\text { sayısı }\end{array}$ & Makale başlığındaki sözcük sayısı & $\min =1 ; \operatorname{maks}=36 ;$ ortn $=13 ; \bar{x}=13 ; \mathrm{s}=4,57$ \\
\hline $\begin{array}{l}\text { Özdeki sözcük } \\
\text { sayısı }\end{array}$ & Makalenin özündeki (abstract) sözcük sayısı & $\min =1 ; \operatorname{maks}=864 ;$ ortn $=175 ; \bar{x}=178 ; s=77,95$ \\
\hline Referans sayıs1 & Makalenin kaynakçasındaki referans sayısı & $\min =0 ;$ maks $=950 ;$ ortn $=27 ; \bar{x}=30 ; s=22,10$ \\
\hline $\begin{array}{l}\text { Dergi etki faktörü - } \\
2 \text { yılllk }\end{array}$ & $\begin{array}{l}\text { Makalenin yayımlandığı derginin iki yıllık dergi } \\
\text { etki faktörü (Kaynak: JCR) }\end{array}$ & $\begin{array}{l}\min =0 ; \text { maks }=74,700 ; \text { ortn }=1,60 ; \bar{x}=2,12 \\
\mathrm{~s}=2,78\end{array}$ \\
\hline Makale etki puanı & $\begin{array}{l}\text { Makalenin yayımlandığı derginin makale etki } \\
\text { puanı (Kaynak: JCR) }\end{array}$ & $\begin{array}{l}\min =0 ; \text { maks }=31,320 ; \text { ortn }=0,36 ; \bar{x}=0,51 ; \\
s=1,04\end{array}$ \\
\hline $\begin{array}{l}\text { Dergi etki faktörü - } \\
5 \text { yıllık }\end{array}$ & $\begin{array}{l}\text { Makalenin yayımlandığı derginin beş yıllık dergi } \\
\text { etki faktörü (Kaynak: JCR) }\end{array}$ & $\begin{array}{l}\min =0 ; \text { maks }=72,100 ; \text { ortn }=1,61 ; \bar{x}=2,12 \\
\mathrm{~s}=2,73\end{array}$ \\
\hline Çeyreklik & $\begin{array}{l}\text { Makalenin yayımlandığı derginin ilgili konudaki } \\
\text { dergiler arasındaki çeyreklik değeri (Kaynak: JCR) }\end{array}$ & $\begin{array}{l}\text { Q1 (ref): } 986(\% 22) ; \mathrm{Q} 2: 861(\% 19) ; \mathrm{Q} 3: 936 \\
\text { (\%21); Q4: } 1184(\% 26) ; \mathrm{Q} 99: 554(\% 12)\end{array}$ \\
\hline Yabancı ülke & $\begin{array}{l}\text { Makalenin yabancı ülke(ler) ile işbirliği yapılarak } \\
\text { hazırlanıp hazırlanmadığı }\end{array}$ & Evet (ref): 857 (\%19); Hayır: 3664 (\%81) \\
\hline $\begin{array}{l}\text { Farklı ülkelerden } \\
\text { yazar sayısı }\end{array}$ & $\begin{array}{l}\text { Varsa makalenin farklı ülkelerden ortak yazar } \\
\text { sayısı }\end{array}$ & $\min =0 ; \operatorname{maks}=44 ;$ ortn $=0 ; \bar{x}=0,5 ; \mathrm{s}=2,62$ \\
\hline Örgüt sayısı & Makale yazarlarının çalıştıkları örgüt sayısı & $\min =0 ;$ maks $=237 ;$ ortn $=2 ; \bar{x}=2,7 ; s=11,57$ \\
\hline Farklı örgüt sayısı & Makale yazarlarının çalıştıkları tekil örgüt sayısı & $\min =0 ;$ maks $=208 ;$ ortn $=1 ; \bar{x}=1,6 ; s=8,90$ \\
\hline $\begin{array}{l}\text { Konu kategorisi } \\
\text { sayısı }\end{array}$ & Makalenin dizinlendiği konu sayısı & $\min =1 ;$ maks $=6 ;$ ortn $=1 ; \bar{x}=1,6 ; s=0,80$ \\
\hline Dizin & Makalenin hangi dizin(ler)de dizinlendiği & $\begin{array}{l}\text { SCI (ref): } 4072(\% 90) \text {; SSCI: } 236(\% 5) \text {; } \\
\text { AHCI: } 52(\% 1) \text {; SCI-SSCI: } 135(\% 3) \text {; SCI- } \\
\text { AHCI: } 6(\% 0) \text {; SSCI-AHCI: } 8(\% 0) ; \\
\text { Belirtilmemiş: } 12(\% 0)\end{array}$ \\
\hline Konu & $\begin{array}{l}\text { Makalenin hangi konular altında dizinlendiği } \\
\text { Not: Makalenin dizinlendiği ilk konu temel } \\
\text { alınmıştır. }\end{array}$ & $\begin{array}{l}\text { Yaşam Bil ve Biyotıp (ref): } 2501 \text { (\%55); Fen } \\
\text { Bil: } 818(\% 18) \text {; Teknoloji: } 888 \text { (\%20); Sosyal } \\
\text { Bil: } 266(\% 6) \text {; Sanat ve İnsan Bil.: } 42(\% 1) \text {; } \\
\text { Belirtilmemiş: } 6(\% 0)\end{array}$ \\
\hline UBYT desteği & $\begin{array}{l}\text { Makalenin TÜBİTAK UBYT desteği alıp almadığ1 } \\
\text { (Kaynak: UBYT 2006-2015 ödeme verileri) }\end{array}$ & Evet (ref): 1679 (\%37); Hayır: $2842(\% 63)$ \\
\hline Destekli araştırma & $\begin{array}{l}\text { Makalenin desteklenen araştırma projelerine } \\
\text { dayanıp dayanmadığı }\end{array}$ & Evet (ref): 1172 (\%26); Hayır: 3349 (\%74) \\
\hline Açık erişim & $\begin{array}{l}\text { Makalenin açık erişim dergide yayımlanıp } \\
\text { yayımlanmadığ } 1\end{array}$ & Evet (ref): 937 (\%21); Hayır: 3584 (\%79) \\
\hline
\end{tabular}

Notlar ve kısaltmalar: Tanımlayıcı istatistikler aralıklı/oranlı ölçümle veri toplanmış değişkenler için örneklemden elde edilen minimum ( $\mathrm{min}$ ), maksimum (maks), ortanca (ortn), ortalama $(\bar{x})$, standart sapma $(s)$; kategorik değişkenler içinse sıklık $(n)$ ve yüzde $(\%)$ değerleri verilmiştir (kategorik değişkenlerin ilk grubunda yer alan "ref” kısaltması istatistik testlerde referans alınan grubu temsil etmektedir). Kaynak belirtilmeyen veriler ya doğrudan Web of Science'tan (WoS) alınmıştır ya da WoS verilerine dayanmaktadır. JCR: Journal Citation Reports; Q1-Q4: JCR' de 1., 2, 3 ve 4. çeyrekliklerde listelenen dergileri, $Q 99$ ise henüz JCR'de listelenmeyen dergileri belirtmektedir. SCI: Science Citation Index Expanded; SSCI: Social Science Citation Index; AHCI: Arts \& Humanities Citation Index; Bil: Bilimleri. UBYT: TÜBITAK Uluslararası Bilimsel Yayınları Destekleme Programı. 
2. Dergi düzeyi değişkenler: TR adresli makalelerin yayımlandığı dergilerin iki ve beş yıllık dergi etki faktörü, ${ }^{3}$ makale etki puanı (MEP) ${ }^{4}$ ve JCR'de listelenen çeyreklik (quartile) $^{5}$ değeridir. Makalelerin yarısı etki faktörü 1,6 ve daha düşük dergilerde yayımlanmıştır. Ortalama makale etki puanı ise dünya ortalamasının $(1,000)$ oldukça altındadır ( rtanca $=0,36, \bar{x}=0,51$ ). Makalelerin \%22'si Q1, \%19'u Q2 dergilerinde, geri kalanı ise Q3, Q4 ve dergi etki faktörü hesaplanmadığı için çeyreklik değeri olmayan dergilerde yayımlanmıştır. Dergi çeyreklik değeri kategorik bir değişken olduğu için istatistik testlerde birinci çeyreklikteki (Çeyreklik-Q1) dergilerde yayımlanan makaleler referans olarak alınmıştır.

3. Iş̧birliği düzeyi değişkenler: Makalenin yabancı ülke(ler) ile işbirliği yapılarak yayımlanıp yayımlanmadığı, varsa farklı ülkelerden yazar sayısı, yazarların kaç örgütte ve kaç farklı örgütte çalıştıklarıdır. TR adresli makalelerin \%19'u yabancı ülkelerle işbirliği yapılarak hazırlanmıştır. Yabancı ülke değişkeni kategorik değişken olup işbirliği ile yayımlanan makaleler referans değeri olarak alınmıştır. Farklı ülkelerden ortak yazar sayısı oldukça düşüktür ( ortanca $=0, \bar{x}=0,5, \mathrm{~s}=2,6$ ). İşbirliği genellikle bir ya da iki (farklı) kurumla sınırlıdır.

4. Dizinleme düzeyi değişkenler: Makalenin yayımlandığı derginin kaç WoS konu kategorisi altında listelendiği, hangi WoS dizin(ler)inde ve hangi genel konu(lar) altında dizinlendiğidir. Makalelerin yarısı bir konu kategorisi altında ( $\bar{x}=1,6, \mathrm{~s}=8,0) ; \% 90$ ’1 SCI'de, \%5'i SSCI'de, \%1'i AHCI'de dizinlenmiştir. Makalelerin yarıdan çoğu (\%55) Yaşam Bilimleri ve Biyotıp, \%18'i Fen Bilimleri, \%20'si Teknoloji konularındadır. Sosyal Bilimler (\%6) ve Sanat ve İnsan Bilimleri (\%1) konulu makalelerin oranı ise oldukça düşüktür. Dizin ve konu değişkenleri kategorik değişkenlerdir. İlkinde SCI'de, ikincisinde Yaşam Bilimleri ve Biyotıp konusu altında dizinlenen makaleler referans değeri olarak alınmıştır. ${ }^{6}$

5. Destek düzeyi değişkenler: Makalenin TÜBİTAK UBYT Programı desteği alıp almadığı ya da bir başka kurum tarafından desteklenip desteklenmediğidir. Makalelerin \%37'si UBYT desteği almış, \%26'sı ise başka destekli projeler sonucu üretilmiştir. Her iki değişken için de desteklenen makaleler referans değeri olarak alınmıştır.

6. Açık erişim değişkeni: Makalenin açık erişim olarak yayımlanıp yayımlanmadığıdır. Herhangi bir şekilde ücret ödenerek erişilen dergilerde yayımlanan makaleler kapalı erişim, karma (hibrit) dergilerde yayımlanan ama ücretsiz erişilebilen ya da açık erişim

\footnotetext{
${ }^{3}$ Dergi etki faktörü (journal impact factor) bir dergide belli bir sürede yayımlanan makalelere yapılan "ortalama" atıf sayısıdır. Belli bir yılda (n) bir derginin önceki iki $(n-2)$ ya da beş $(n-5)$ yılda yayımladı̆̆ atıfların ortalamaları sırasıyla iki yıllık (JIF2) ve beş yıllık (JIF5) dergi etki faktörü olarak adlandırılmaktadır. Dergi etki faktörünün hesaplanmasında üç yıllık atıf penceresi de kullanılmaktadır (Scopus).

${ }^{4}$ Dergi makale etki puanının (MEP) hesaplanmasında makalelerin dergide yayımlanmasından sonra ilk beş yılda aldığı atıf sayıları kullanılmakta, fakat makalelere yapılan atıflar atıf yapan dergilerin etki faktörlerine göre ağırlıklandırılmaktadır. MEP değeri 1,000 dünya ortalamasını temsil etmekte (Article Influence, 2021), bu değerin üstünde MEP değeri olan dergilerde yayımlanan makalelerin etkisinin (influence) ortalamanın üzerinde olduğu kabul edilmektedir.

${ }^{5}$ Dergi etki faktörünü hesaplamak için her dergi en az bir konu kategorisi altında sinıflanmakta ve her konu altındaki dergiler etki faktörlerine göre sıralanarak dört çeyrekliğe ayrılmaktadır. En yüksek etki faktörü olan ilk çeyreklikteki dergiler Q1 dergileri, ikinci en yüksek olanlar Q2 dergileri vd. olarak adlandırılmaktadır (Tonta ve Akbulut, 2020, s. 1625).

${ }^{6}$ Birden fazla konu altında dizinlenen makalelerde analiz için WoS'ta listelenen ilk konu temel alınmıştır.
} 
dergilerde yayımlanan makaleler açık erişim olarak sınıflandırılmıştır. TR adresli makalelerin \%21'i açık erişim olarak yayımlanmıştır. Açık erişim makaleler referans değeri olarak alınmıştır.

\section{Yöntem}

Atıf verileri normal dağılıma uymayan, sıfır değerini de içeren kesikli sayma verileridir (count data). Sayma verilerini analiz etmek için çeşitli regresyon modelleri kullanılmaktadır (Baydemir, 2014; Desjardins, 2016; Didegah ve Thelwall, 2013a, 2013b; Dinarcan, 2018; Tüzen ve Erbaş, 2017; Zeileis, Kleiber ve Jackman, 2008). Sayma verilerindeki sıfır değerleri "yapisal" (structural) olabilir ya da bu değerler örneklem sürecinin bir fonksiyonu olarak elde edilmiş olabilir (Desjardins, 2016, s. 449-450). Örneğin, aylık ortalama benzin tüketimi üzerine yapılan bir araştırmada bazı denekler arabası olmadığı için, bazı deneklerse arabaları olduğu halde o ay arabalarını çeşitli nedenlerle (örneğin COVID-19 kısıtlamaları) kullanmadıkları için hiç benzin tüketmemiş olabilirler. Bunlardan ilki yapısal sıfır, ikincisi ise örneklemden kaynaklanan sıfır değerine örnektir. Başka bir deyişle, daha sonra yapılacak bir başka ölçümde arabası olan deneklerin sıfırdan farklı benzin tüketimi rapor etme olasılığ varken, arabası olmayan denekler için böyle bir olasılık yoktur. Yapısal sıfır içeren veriler için sıfır yı̆̆gılımlı (zero-inflated) regresyon modelleri kullanılır.

Türkiye adresli makalelere yapılan atıflar normal dağılıma uymamaktadır. Atıf verilerinin varyansı (40) aritmetik ortalamasının (17) iki katından daha fazladır. ${ }^{7}$ Az sayıdaki makaleye çok sık atıf yapılırken birçok makaleye ya hiç atıf yapılmamakta ("sıfır atıf”) ${ }^{8}$ ya da çok seyrek atıf yapılmaktadır (Nicolaisen ve Frandsen, 2019). Bir makalenin sıfır atıf engelini aşarak ilk atıfını alması önemlidir. Çünkü en az bir atıf alan makalelerin 2., 3., n.'inci atıfı alma olasılığı hiç atıf almayan makalelere oranla giderek yükselmektedir (Didegah ve Thelwall, 2013a, s. 865). ${ }^{9}$ Aradan uzun sayılabilecek belli bir süre geçmesine karşın (atıf penceresi ortalama yedi buçuk y1l) örneklemde yer alan 391 makaleye (bütün makalelerin \%8,6's1) henüz hiç atıf yapılmamıştır. ${ }^{10}$ Bazı makalelere aradan ne kadar süre geçerse geçsin belki de hiç atıf yapılmayacaktır. Ama bu makalelerin bundan sonraki yıllarda her zaman atıf alma olasılığ1 bulunduğundan bu makalelere ait (sıfır) atıf sayıları "yapısal sıfır” değildir. Bu durumda çarpık dağılımlı ve yapısal sıfırlardan oluşmayan atıf verileri için "engel modeli” (hurdle model) kullanilır.

Engel modeli iki bileşenden oluşur. Modeldeki bir bileşen negatif binom regresyon analizini kullanarak pozitif atıflar ${ }^{11}$ modellemek, diğer bileşen ise binom lojistik regresyon (logit) analizi ile sıfır atıfları modellemek için kullanılır (Jackman ve diğerleri, 2020, s. 27). Engel modeli "her açıklayıcı değişkenin bağımlı değişken üzerindeki etkisini (1) sıfır atıf alan makalelerin azalmasının göreli olasılığını (odds) ve (2) makalelerin pozitif atıf almasındaki etki

\footnotetext{
${ }^{7}$ Atıf sayısına dayanarak hesaplanan dergi etki faktörü, makale etki puanı gibi veriler ve makalelerin ortak yazar sayıları da normal dağılıma uymamaktadır.

${ }^{8}$ Örneğin, 1996-2015 yılları arasında Scopus'ta dizinlenen yaklaşık 73 milyon yayının 26 milyonuna (\%36) hiç atıf yapılmamıştır (Nicolaisen ve Frandsen, 2019, s. 1230).

${ }^{9}$ Bu durum "Matthew etkisi" olarak da bilinir. Bkz. Merton (1968).

${ }^{10} \mathrm{Bu}$ oran 2006-2015 yılları arasında SCI, SSCI ve AHCI'de dizinlenen (226.071) ve hiç atıf almayan (19.120) TR adresli makale oranına $(\% 8,4)$ çok yakındır (25 Nisan 2021).

${ }^{11} \mathrm{Bu}$ çalışmada "pozitif atıf" sözcüğü bir makalenin en az bir (ve daha yüksek) atıf almasını nitelemek için kullanılmıştır.
} 
büyüklüğünü sağlayarak açıklar" ve böylece engel modeli hem bağımsız değişkenlerin makalelerin sıfır atıf alma engelini aşmadaki hem de bu engeli aşan makalelerin daha yüksek pozitif atıf almalarındaki etkisini analiz etmeye olanak sağlar (Tonta ve Akbulut, 2020, s. 16241632).

Sayma verilerini analiz etmek ve engel modelini uygulamak için $\mathrm{R}$ yazılımındaki countreg (v.0.2-1) paketi kullanılmıştır (Zeileis, Kleiber ve Jackman, 2008). Bulguları yorumlamak için tanımlayıcı istatistikler ve istatistik test sonuçlarından (katsayılar, güven aralıkları vd.) yararlanılmıştır. İstatistik testler için $p$ değeri 0,05 olarak kabul edilmiştir. Engel modelinde göreli olasılıklar oranı (odds ratio, ya da "bahis" oranı) bağımlı değişkenle bağımsız değişkenler arasındaki ilişkileri ve etki büyüklüğünü yorumlamak için kullanılmıştır. Çok genel olarak, göreli olasılıklar oranı bir olayın iki farklı grup için olma olasılıklarının birbirine bölünmesiyle elde edilir. Örneğin, belli bir virüse karşı bir aşının 0,9 , bir başka aşının ise 0,5 olasılıkla etkili olduğunu varsayalım. İlk aşının etkili olma olasılı̆̆ $19: 1$, ikincisininkiyse 1:1'dir (yani ikinci aşının etkili olma olasılığıyla olmama olasılığı 0,5 olup birbirine eşittir). İki olasılığın birbirine bölünmesiyle elde edilen göreli olasılıklar oranı ilk aşının ikinci aşıya göre virüse karşı dokuz kat daha etkili olduğu anlamına gelir.

Engel modeli analizi sonucu değişkenler için hesaplanan üstel lojistik regresyon katsayıları (exponentiated coefficients) göreli olasılıklar oranlarını vermektedir. Lojistik regresyon modelinde makalelerin bir ve daha fazla atıf alma olasılığının sıfır atıf alma olasılığına bölünüp çıkan sonucun logaritması alınarak hesaplanan göreli olasılıklar oranı tahmin edilir (Didegah ve Thelwall, 2013a, s. 865). Göreli olasılıklar oranı bir bağımsız değişkende meydana gelen bir standart sapmalık değişimin bağımlı değişken (atıf sayısı) üzerindeki etkisini yüzde olarak verir (Didegah ve Thelwall, 2013b, s. 1059). Göreli olasılıklar oranı 1'den büyükse bağımsız değişkenle bağımlı değişken arasında pozitif, 1'den küçükse negatif bir ilişki olduğunu gösterir. Aralıklı/oranlı ölçümle veri toplanan değişkenler için göreli olasılıklar oranı (diğer değişkenlerin etkisi sabit tutulmak kaydıyla) bağımsız değişkendeki bir birimlik değişismin bağımlı değişken üzerindeki etkisini (artış ya da azalma) yorumlamak için kullanılır. Kategorik değişkenlerde ise bir bağımsız değişkende referans olarak alınan grubun (faktörün) bağımlı değişken üzerindeki etkisi temel alınır ve diğer grup ya da grupların bağımlı değişken üzerindeki etkisi buna göre yorumlanır.

Şekil 1'deki asılı karekök grafiği (hanging rootogram) $x$ ekseninde beklenen ve gözlenen atıf sayıları $(0,1,2, \ldots n$ atıf -gösterim amacıyla 100 ile sınırlandırılmıştır), $y$ ekseninde ise o sayıda atıf alan makale sayısının karekökü alınarak gösterilmektedir (Kleiber ve Zeileis, 2016, s. 297). Grafikteki çubuklar $x$ eksenine ne kadar yakınsa veriler modele o kadar uygundur, anlamına gelmektedir (Tüzen ve Erbaş, 2017, s. 5832). Bazı ufak tefek uyumsuzluklar gözlense de Şekil 1 atıf verilerinin engel negatif binom modeli ile analize uygun olduğunu göstermektedir.

\section{Bulgular ve Yorum}

Engel modelinin sonuçları (katsayı, $p$ değeri, standart hata, üstel katsayı), yayılım ve logolabilirlik (log-likelihood) parametreleri, Akaike ve Bayes bilgi ölçütleriyle (AIC ve BIC) 
birlikte Tablo 2'de verilmektedir. Yöntem kısmında da değinildiği gibi, engel modeli hem pozitif atıf alan makaleler (negatif binom kısmı) hem de henüz hiç atıf almayan (sıfır atıf) makaleler (logit) için katsayıları üretmektedir. Tablo 2'nin solundaki "sayma modeli" kısmı bağımsız değişkenlerin pozitif atıf almış TR adresli makaleler $(n=4130)$ üzerindeki etkisini göstermektedir. Üçüncü sütunda "katsayı", 4. sütunda "p" değeri (yani 0,05, 0,01 ve 0,001 düzeylerinde istatistiksel olarak anlamlı etkisi olan değişkenleri), 5. sütunda standart hata, 6 . sütunda ise üstel katsayı (göreli olasılıklar oranı) verilmektedir. Tablo 2'nin sağında ise logit regresyon analizi testi sonuçlarına göre bağımsız değişkenlerin TR adresli makalelerin "sıfır atıf” engelini aşmasındaki (yani en az bir atıf almasındaki) etkisi aynı değerlerle gösterilmektedir (7., 8., 9. ve 10. sütunlar). ${ }^{12}$ Aşağıda bağımsız değişkenlerin makalelerin hem pozitif atıf sayısını artırmadaki hem de sıfır atıf engelini aşmasındaki etkileriyle ilgili bulgular sunulmakta, istatistiksel olarak anlamlı etkisi olan bağımsız değişkenlerin \%95 güven aralıkları (GA) da verilmektedir.

\section{Şekil 1}

Engel modeli asılı karekök grafiği

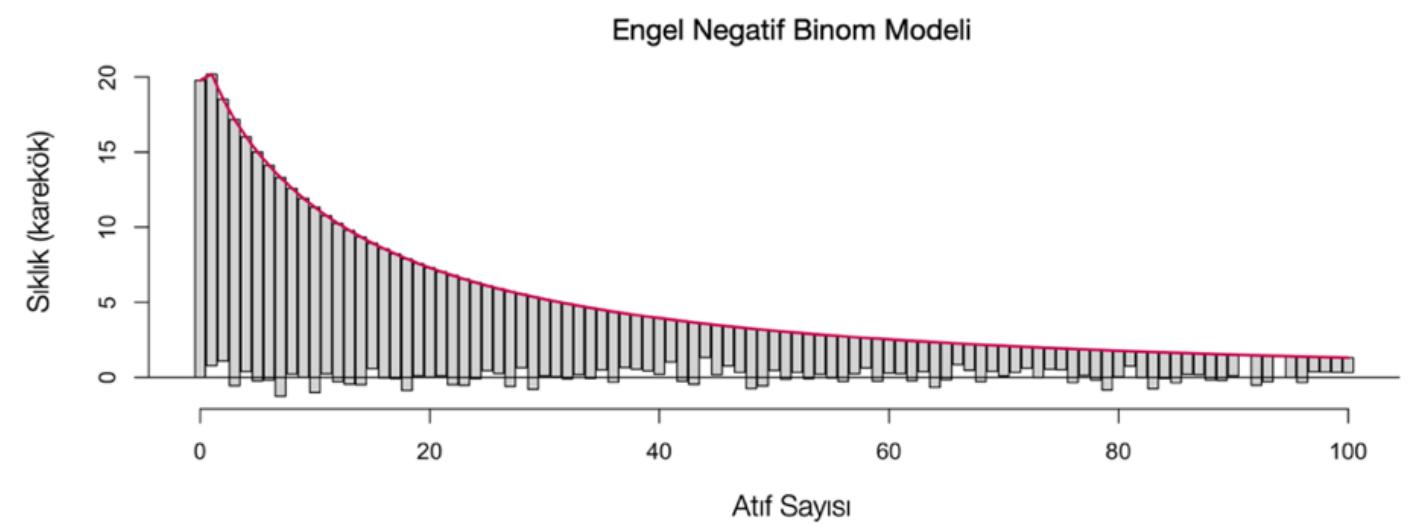

Engel modelinin sayma verisi kısmındaki bulgulara göre, dergi ve makale düzeyi bazı değişkenler pozitif atıf almış olan makalelerin atıf sayılarını istatistiksel olarak anlamlı düzeyde etkilemektedir. Örneğin, beş yıllık dergi etki faktöründeki (JIF5) bir birimlik artış ortalama atıf oranını \%53,6 artırmaktadır (\%95 GA: \%38,1-\%70,8). JIF5 makalelerin ilk atıf alma (yani sıfır atıf engelini aşma) göreli olasılıklar oranını da istatistiksel olarak anlamlı ve pozitif yönde etkilemektedir. JIF5 değerinde bir birimlik artış sıfır atıf engelini aşan makalelerin oranını ortalama 2,64 kat artırmaktadır. Başka bir deyişle, JIF5 değişkeni hiç atıf almayan makale sayısının azalmasında önemli rol oynamaktadır. JIF5'i nispeten yüksek dergilerde yayımlanan ve henüz hiç atıf almamış olan makalelerin ilk atıflarını alma olasılı̆̆g JIF5'i yüksek olmayan dergilerde yayımlanan ve hiç atıf almamış makalelere oranla ortalama \%164 daha yüksektir (\%95 GA: \%50-\%366).

\footnotetext{
${ }^{12}$ Yayın yılına göre makalelerin aldıkları atıf sayıları düzgeleştirilmemiş (normalize edilmemiş), ancak yayın yılının etkisini kontrol etmek için yayın yılı modelin hem negatif binom hem de logit bileşenlerine girilmiştir (Didegah ve Thelwall, 2013a, s. 864). Yayın yılı daha eski olan makaleler doğal olarak genelde nispeten daha yüksek sayıda atıf almaktadır. Örneğin, 2007'de yayımlanan bir makalenin aldığı ortalama atıf sayısı 2006'da yayımlanan bir makaleninkine göre ortalama \%10,7 daha düşüktür.
} 
Uluslararası Dergilerde Yayımlanan Türkiye Adresli Makalelerin Atıf Etkisini Artıran Faktörler

Tablo 2

Engel modeli sonuçları

\begin{tabular}{|c|c|c|c|c|c|c|c|c|c|}
\hline \multicolumn{6}{|c|}{ Sayma kısmı (negatif binom - log link ile) } & \multicolumn{4}{|c|}{ Sifir k1smı (binom logit link ile) } \\
\hline $\begin{array}{c}\text { Değişken } \\
\text { türü }\end{array}$ & Değişken adı & $\begin{array}{c}\text { Katsay } 1 \\
(\beta)\end{array}$ & $\mathrm{p}$ & $\begin{array}{l}\text { Standart } \\
\text { Hata }\end{array}$ & $\begin{array}{l}\text { Katsayının } \\
\text { üssü } \exp (\beta)\end{array}$ & $\begin{array}{l}\text { Katsay } 1 \\
(\beta)\end{array}$ & $\mathrm{p}$ & $\begin{array}{c}\text { Standart } \\
\text { Hata }\end{array}$ & $\begin{array}{c}\text { Katsayının } \\
\text { üssü } \exp (\beta)\end{array}$ \\
\hline \multirow{5}{*}{ } & Yayın y1lı & $-0,114$ & & -- & 0,893 & $-0,112$ & & -- & 0,894 \\
\hline & Yazar sayısı & $-0,006$ & & -- & 0,994 & 0,075 & $*$ & 0,034 & 1,078 \\
\hline & Başlıktaki sözcük sayısı & $-0,004$ & & 0,004 & 0,996 & 0,034 & $*$ & 0,014 & 1,035 \\
\hline & Özdeki sözcük sayısı & 0,002 & $* * *$ & 0,000 & 1,002 & 0,001 & & 0,001 & 1,001 \\
\hline & Referans say1s1 & 0,013 & $* * *$ & 0,001 & 1,013 & 0,021 & $* * *$ & 0,004 & 1,021 \\
\hline \multirow{7}{*}{$\begin{array}{l}\overline{0} \\
\dot{0} \\
0\end{array}$} & Dergi etki faktörü - 2 yıllık & $-0,202$ & $* * *$ & 0,046 & 0,817 & $-0,151$ & & 0,254 & 0,860 \\
\hline & Makale etki puanı & $-0,290$ & $* * *$ & 0,048 & 0,748 & $-0,151$ & & 0,393 & 0,860 \\
\hline & Dergi etki faktörü - 5 yıllık & 0,429 & $* * *$ & 0,054 & 1,536 & 0,971 & $* * *$ & 0,290 & 2,639 \\
\hline & Çeyreklik-Q2 & $-0,035$ & & 0,059 & 0,966 & 0,685 & $*$ & 0,345 & 1,983 \\
\hline & Çeyreklik-Q3 & $-0,248$ & $* * *$ & 0,067 & 0,780 & 0,817 & $*$ & 0,353 & 2,263 \\
\hline & Çeyreklik-Q4 & $-0,580$ & $* * *$ & 0,073 & 0,560 & 0,180 & & 0,394 & 1,197 \\
\hline & Çeyreklik-Q99 & $-0,490$ & $* * *$ & 0,094 & 0,613 & 0,233 & & 0,474 & 1,262 \\
\hline \multirow{4}{*}{ 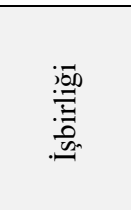 } & Yabancı ülke (Hayır) & $-0,245$ & $* * *$ & 0,055 & 0,783 & $-0,056$ & & 0,443 & 0,946 \\
\hline & Farklı ülkelerden yazar sayısı & $-0,046$ & $* *$ & 0,015 & 0,955 & 0,002 & & 0,345 & 1,002 \\
\hline & Örgüt sayısı & 0,069 & $* * *$ & 0,007 & 1,072 & 0,006 & & 0,075 & 1,006 \\
\hline & Farklı örgüt sayısı & 0,004 & & -- & 1,004 & 0,212 & & 0,119 & 1,236 \\
\hline \multirow{12}{*}{ 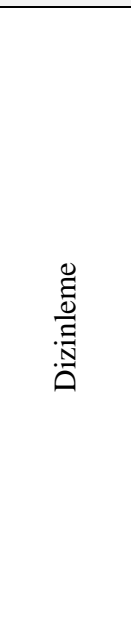 } & Konu kategorisi sayıs1 & 0,079 & $* * *$ & 0,022 & 1,082 & 0,192 & & 0,099 & 1,212 \\
\hline & Dizin (SSCI) & $-0,212$ & & 0,135 & 0,809 & $-0,123$ & & 0,494 & 0,884 \\
\hline & Dizin (AHCI) & $-2,375$ & $* * *$ & 0,594 & 0,093 & $-0,755$ & & 0,834 & 0,470 \\
\hline & Dizin (SCI-SSCI) & 0,088 & & 0,100 & 1,092 & 0,929 & & 0,550 & 2,532 \\
\hline & Dizin (SCI-AHCI) & $-0,685$ & & 0,466 & 0,504 & 12,420 & & 913,100 & 248670,900 \\
\hline & Dizin (SSCI-AHCI) & $-0,163$ & & 0,431 & 0,850 & $-0,945$ & & 1,220 & 0,389 \\
\hline & Dizin (Dizinlenmemiş) & 0,476 & & 0,310 & 1,610 & 12,360 & & 605,700 & 233580,500 \\
\hline & Konu (Fen Bilimleri) & 0,046 & & 0,052 & 1,047 & $-0,208$ & & 0,185 & 0,812 \\
\hline & Konu (Teknoloji) & $-0,001$ & & 0,049 & 0,999 & 0,005 & & 0,184 & 1,005 \\
\hline & Konu (Sosyal Bilimler) & 0,053 & & 0,131 & 1,055 & $-0,207$ & & 0,500 & 0,813 \\
\hline & Konu (Sanat ve İnsan Bilimleri) & 1,017 & & 0,655 & 2,764 & 0,115 & & 0,888 & 0,891 \\
\hline & Konu (Belirtilmemiş) & $-0,846$ & & 0,484 & 0,429 & 14,330 & & 964,300 & 1673931,000 \\
\hline \multirow{2}{*}{ 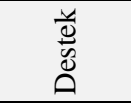 } & UBYT Desteği (Hayır) & 0,056 & & 0,035 & 1,058 & $-0,152$ & & 0,121 & 0,859 \\
\hline & Destekli araştırma (Hayır) & $-0,074$ & & 0,041 & 0,929 & $-0,366$ & & 0,168 & 0,694 \\
\hline \multirow[t]{4}{*}{ 䇋 } & Açık erişim (Hayır) & $-0,009$ & & 0,045 & 0,991 & 0,052 & & 0,136 & 1,053 \\
\hline & (Sabit) & 230,200 & $* * *$ & 0,118 & $9,21 E+99$ & 224,300 & $* * *$ & 0,637 & $2,58 \mathrm{E}+97$ \\
\hline & $\mathrm{N}=4130$ & & & & & $\mathrm{~N}=391$ & & & \\
\hline & $\begin{array}{l}\text { Yayllım parametresi (theta): } 0,92 \\
\text { Log-olabilirlik (Log-likelihood): } \\
\text { Akaike Information Criterion (AI } \\
\text { Bayesian Information Criterion }( \\
\text { Not: }{ }^{*} p<0,05 ; * * p<0,01 ; * * *\end{array}$ & $\begin{array}{l}86 \\
-1,578 \mathrm{e}+\mathrm{C} \\
\mathrm{IC}): 31685 \\
\mathrm{BIC}): 321 \\
p<0,001\end{array}$ & $\begin{array}{l}04 ; \mathrm{SL} \\
5 . \\
02 .\end{array}$ & D (serbes & k derecesi): & & & & \\
\hline
\end{tabular}


İki yıllık dergi etki faktörü (JIF2) ve makale etki puanı (MEP) ise, beklenenin aksine, ${ }^{13}$ makalelerin pozitif atıf almasında etkili değildir. Tam tersine, bu değişkenler makalelerin aldığ ortalama atıf oranında sirasiyla \%18,3 (\%95 GA: \%10,6-\%24,4) ve \%25,2'lik (\%95 GA: $\% 17,8-\% 31,9)$ istatistiksel olarak anlamlı bir düşüşe neden olmaktadır. JIF2 ve MEP değişkenlerinin makalelerin sıfır atıf engelini aşmasında da anlamlı bir etkisi yoktur. JIF2'nin başka çalışmalarda (örneğin, Didegah ve Thelwall, 2013a, 2013b; Fronzetti Colladon, D’Angelo ve Gloor, 2020) atıf sayısını artırırken bu çalışmada artırmamasının birkaç nedeni olabilir. Öncelikle, JIF2 atıf örüntüleri birbirinden farklı disiplinler arasındaki atıf etkilerini karşılaştırmak için kullanılabilecek iyi bir gösterge değildir (Liu ve Fang, 2020, s. 2). Dergi etki faktörünün hesaplanmasında kullanılan iki yıllık atıf penceresi TR adresli makalelerin yayımlandığı çeşitli disiplinlerdeki dergiler açısından sıfır atıf engelini aşmak ve kayda değer sayıda atıf almak için yeteri kadar uzun bir süre değildir. Bu makalelere yapılan atıfların çoğunun genellikle nispeten daha düşük JIF2 değeri olan dergilerde yayımlanan diğer (TR adresli) makalelerden gelmesi JIF2'nin TR adresli makalelerin atıf sayısını etkilememesinin bir diğer nedeni olabilir (Akçiğit ve Özcan-Tok, 2020; Kamalski ve diğerleri, 2017). JIF2 ve MEP değişkenlerinin TR adresli makalelerin hem sıfır atıf engelini aşmada hem de daha yüksek sayıda atıf almasında etkisi olmadığı yönündeki bulgu TÜBİTAK UBYT desteği verilen makalelerin JIF ve MEP değerlerinin destek verilmeyen makalelerinkinden daha yüksek olmadığı yönündeki bulguları kısmen desteklemektedir (Tonta ve Akbulut, 2020, s. 1633).

Öte yandan, beş yıllık atıf sayılarına dayanmasına karşın MEP değişkeninin TR adresli makalelerin pozitif atıf almasında olumlu bir etkisinin olmaması bu makalelerin nispeten düşük etki faktörlü dergilerde yayımlanmış makalelerden az sayıda atıf almış olabileceğini düşündürmektedir. Nitekim TR adresli makalelerin yayımlandığı dergilerin \%90'ının MEP değerleri dünya ortalamasının $(1,000)$, yaklaşık üçte ikisinin ise dünya ortalamasının yarısının altındadir (ortanca $=0,360, \bar{x}=0,509$ ).

TR adresli makalelerin yayımlandığı dergilerin çeyreklik değerlerinin makalelerin hem pozitif atıf sayısına hem de sıfır atıf engelini aşmasına istatistiksel olarak anlamlı etkisi vardır. Q3 ve Q4 dergilerinde ve henüz JCR çeyreklik değeri atanmamış dergilerde yayımlanan makalelerin ortalama atıf oranları Q1 dergilerinde yayımlanan makalelerinkine kıyasla ortalama $\% 22, \% 47$ ve $\% 38,7$ daha düşüktür (sırasıyla $\% 95$ GA: $\% 11,1-\% 31,5 ; \% 35,4-\% 51,5$; $\% 24,4-\% 49,9) .{ }^{14}$ Q2 ve Q3 dergilerinde yayımlanan ancak henüz hiç atıf almamış olan makalelerin Q1 dergilerinde yayımlanan ve hiç atıf almamış makalelere oranla ilk atıf alma göreli olasılıklar oranı sırasıyla 1,98 kat ve 2,26 kat (\%95 GA: 1,01-3,90 kat ve 1,13-4,52) daha azalmaktadır. Q2 dergilerinde yayımlanan ve henüz hiç atıf almamış makalelerin Q1 dergilerindeki hiç atıf almamış makalelerle karşılaştırıldığında ilk atıf alma göreli olasılık oranları yarı yarıya düşmesine karşın, aynı etki makalelerin pozitif atıf almasında ortadan kalkmaktadır. Pozitif atıf alan ve Q2 dergilerinde yayımlanan makaleler referans değeri olarak alınan Q1 dergilerinde yayımlanan makalelerinkine oranla ortalama \%3,5 daha az atıf almaktadır ama bu fark istatistiksel açıdan anlamlı değildir $(p=0,557)$. Bunun temel nedeni disiplinlere göre Q1 ve Q2 dergilerinin etki faktörlerinin ve dolayısıyla aldıkları ortalama atıf sayılarının birbirinden farklı olmasıdır. Belli bir alanda yayımlanan ama Q2 dergisi olarak

\footnotetext{
${ }^{13}$ JIF2, JIF5 ve MEP değişkenleri arasındaki ikili korelasyon değerleri (Pearson's $r$ ) 0,9'un üzerindedir.

${ }^{14}$ Çeyreklik değeri olmayan dergilerin büyük bir kısmı Türkiye'de yayımlanan dergilerden oluşmaktadır.
} 
sınıflanan bir dergi bir başka alandaki Q1 dergisinden daha yüksek etki faktörüne sahip olabilir (Sivertsen, 2016, 2019). Bir diğer neden ise Q3 ve Q4 dergilerinde yayımlanan makalelerin toplam makale sayısına oranı dünyada \%35-\%42 iken (Liu, Guo ve Zuo, 2018; Miranda ve Garcia-Carpintero, 2019), bu oran TR adresli makaleler için \%59'dur (Q3: \%21; Q4: \%26; çeyreklik değeri atanmamış dergiler: \%12).

Makale düzeyi bazı değişkenlerin, makalelerin hem pozitif atıf sayısının artmasında hem de hiç atıf almayan makale sayısının azalmasında olumlu etkisi bulunmaktadır. Makalelerin sonunda yer alan her referans ortalama pozitif atıf oranını \%1,3 (\%95 GA: \%1,0-\%1,5) sifir atıf engelini aşma göreli olasılıklar oranını ise \%2,1 (\%95 GA: \%1,3-\%3,1) artırmaktadır. Makale özlerindeki sözcük sayısının pozitif atıf sayısının artmasına etkisi -istatistiksel olarak anlamlı olsa da- sıfıra yakındır (\%95 GA: \%0,1-\%0,2). Makalenin yazar sayısı, başlıktaki sözcük sayısı ve referans sayısı henüz hiç atıf almamış olan makalelerin ilk atıf alma göreli olasılıklar oranını pozitif yönde etkilemektedir. Ortak yazar, başlıktaki sözcük ve referans sayısında bir birimlik artış sıfır atıf engelini aşan makalelerin oranını ortalama \%7,8 (\%95 GA: 0,8-\%15,2), \%3,5 (\%95 GA: \%0,7-\%6,3) ve \%2,1 (\%95 GA: \%1,2-\%3,0) artırmaktadır. Bu bulgular, ortak yazarlı ve özellikle uluslararası işbirliği yapılarak yayımlanan ortak yazarlı makalelerin daha çok atıf aldığ1 yönündeki bulguları desteklemektedir (Akçiğit ve Özcan-Tok, 2020, s. 56; Confraria, Godinho ve Wang, 2017; Fronzetti Colladon, D'Angelo ve Gloor, 2020; Leydesdorff, Bornmann ve Wagner, 2019). Makalelerin referans sayısındaki artışın gerek pozitif atıf sayısını artırmadaki gerekse sıfır atıf alan makale sayısını azaltmadaki olumlu etkisi başka araştırmalardaki bulgularla benzerlik göstermektedir (örneğin Didegah ve Thelwall, 2013a, s. 867; Onodera ve Yoshikane, 2015, s. 757).

Pozitif atıf alan ve yabancı ülkelerle işbirliği yapılmadan yayımlanan makaleler, işbirliği yapılan ve pozitif atıf alan makalelere oranla ortalama \%21,7 (\%95 GA: \%1,7-\%7,3) daha az atıf almaktadır. İşbirliği yapılan örgüt/kurum sayısında bir birimlik artış ise ortalama atıf sayısını \%7,2 (\%95 GA: \%5,8-\%8,6) oranında artırmaktadır. Bu bulgular önceki çalışmaların bulgularıyla uyumludur (örneğin Didegah ve Thelwall, 2013a, 2013b; Fronzetti Colladon, D’Angelo ve Gloor, 2020; Leydesdorff, Bornmann ve Wagner, 2019). İlginçtir, işbirliği yapılan farklı örgüt/kurum sayısının artması makalelerin daha çok atıf almasını olumlu yönde etkilememektedir. Aksine, ortak yazar sayısı sıfır atıf alan makale oranını \%7,8 oranında azaltırken, sıfır atıf engelini aşmış olan makalelerde farklı ülkelerden yazar sayısı arttıkça ortalama atıf oranı \% 4,5 düşmektedir. Bu durumun büyük ölçekli uluslararası projeler (örneğin ATLAS) sonucu yayımlanan ve yazar sayısı çok yüksek olan örneklemdeki az sayıdaki makaleden kaynaklanmış olabileceği düşünülmektedir. İşbirliği düzeyi değişkenlerin, henüz hiç atıf almamış olan makalelerin sıfır atıf engelini aşmasında istatistiksel olarak anlamlı bir etkisi yoktur.

Pozitif atıf alan makalelerin dizinlendiği WoS konu kategorisi sayısı arttıkça ortalama atıf oranı da \%8,3 (\%95 GA: \%3,6-\%13,1) artmaktadır. Ancak konu kategorisi sayısının sıfir atıf alan makale oranını azaltmada anlamlı bir etkisi yoktur. Pozitif atıf alan makalelerin hangi dizinlerde listelendiği ortalama atıf sayısını etkilemektedir. SSCI'de dizinlenen makaleler (bütün makalelerin \%5'i) referans alınan SCI'de dizinlenen makalelere oranla \%19,1 daha az atıf almaktadır ama ikisi arasındaki fark istatistiksel olarak anlamlı değildir $(p=0,114)$. 
AHCI'de dizinlenen makaleler (bütün makalelerin \%1'i) ise SCI'de dizinlenenlere oranla yaklaşık \%90,7 (\%95 GA: \%2,91-\%29,8) daha az atıf almaktadır. Pozitif atıf alan ve birden fazla dizinde listelenen makalelerin ise ortalama atıf sayıları arasında istatistiksel açıdan anlamlı bir fark bulunmamaktadır. ${ }^{15}$ Gerek makalelerin dizinlendiği konu kategorisi sayısı gerekse hangi dizinlerde listelendiklerinin hiç atıf almamış olan makalelerin ilk atıflarını almasında istatistiksel olarak anlamlı bir etkisi yoktur. Başka bir deyişle bu değişkenlerin hiç atıf almayan makale sayısının düşmesine katkısı bulunmamaktadır. Makalelerin hangi temel konu altında dizinlendiği ne pozitif atıf sayısını ne de hiç atıf almayan makalelerin ilk atıf alma göreli olasılıklar oranını artırmaktadır. Ancak bu analizde bir makalenin dizinlendiği temel (ilk) konu kategorisinin dikkate alındığını (ortanca $1 ; \bar{x}=1,6$ ), konu kategorisi sayısı arttıkça atıf sayısının da yaklaşık \%9 oranında arttığını göz önünde bulundurmakta yarar vardır. TR adresli makalelerin gerek sıfır atıf engelini aşmasında gerekse pozitif atıf almasında hangi konu(lar) altında dizinlendiklerinin daha ayrıntılı bir biçimde analiz edilmesi gerekmektedir.

Destek düzeyi değişkenler (makalenin TÜBİTAK UBYT desteği ya da başka bir kaynaktan araştırma desteği alıp almaması) ile açık erişim değişkeninin, makalelerin ortalama atıf sayısını artırmada ya da hiç atıf almayan makalelerin ilk atıflarını almasında istatistiksel olarak anlamlı bir etkisi yoktur. (Hatta istatistiksel açıdan aradaki fark anlamlı olmasa da UBYT desteği almayan makalelerin atıf etkisi alanlarınkinden yaklaşık \%6 daha yüksektir.) Ar-Ge ve proje destekleriyle UBYT desteğinin atıf sayısını artırmada bir etkisi olmadığı yönündeki bulgu daha önceki araştırmaların bulgularını desteklemektedir (Satoğlu, Balkış ve Damar, 2021; Tonta, 2017, 2018; Tonta ve Akbulut, 2020). Ancak bu bulgu UBYT Programı dışında kalan desteklerle yapılan araştırmaların atıf sayısını artırdı̆̆ı yönündeki bulgularla çelişmektedir (Gök, Rigby ve Shapira, 2016; Yan, Wu ve Song, 2018). İlgili çalışmalardan ilkinde (Gök, Rigby ve Shapira, 2016, s. 719), genellikle uluslararası ortaklıklar aracılığıyla araştırmaların yürütüldügü Belçika, Danimarka, Hollanda, Norveç, İsviçre ve İsveç’ten oluşan altı küçük Avrupa ülkesine ait veriler, ikincisinde (Yan, Wu ve Song, 2018) ise bilim, teknoloji, mühendislik, matematik ve tıp verileri kullanılmıştır. Türkiye'nin, yayınlarına daha çok atıf yapılan ABD ve diğer Avrupa ülkeleriyle ortak yürüttüğü araştırmalara dayanan makale sayısının toplam TR adresli makaleler içindeki payı oldukça düşük ve TR adresli makalelerin atıf etkisi dünya ortalamasının altındadır (Akçiğit ve Özcan-Tok, 2020, s. 58; Tonta, 2017).

$\mathrm{Bu}$ bulgulara dayanarak temel araştırma sorusunun yanıtı aşağıda özetlenmektedir.

Beş yıllık dergi etki faktörünün TR adresli makalelerin hem daha çok atıf almasında hem de hiç atıf almayan makale sayısının azalmasında pozitif etkisi vardır. Beş yıllık etki faktörü daha yüksek dergilerde yayımlanan makaleler ortalama \%54 daha fazla atıf almaktadır. $\mathrm{Bu}$ makalelerin hiç atıf almama göreli olasılıklar oranı 2,64 kat daha düşüktür. Derginin iki yıllık etki faktörü ve makale etki puanı değişkenlerinin makalelerin daha çok atıf almasında ya da atıf almayan makale sayısının azalmasında pozitif bir etkisi yoktur. Q1 dergilerinde yayımlanan makaleler diğer çeyrekliklerde yayımlananlara oranla \%3,4 ile \%38,7 oranında daha fazla atıf almaktadır. Q1 dergilerinde yayımlanan ve hiç atıf almayan makale oranları Q2 ve Q3 dergilerindeki oranlardan sırasıyla ortalama $\% 98$ ve $\% 126$ daha düşüktür. Makalelerin

\footnotetext{
${ }^{15}$ Birden fazla dizinde listelenen makale sayısı bütün makalelerin sadece \%4'ünü oluşturmaktadır (SCI-SSCI: 135, SCI-AHCI: 6 ve SSCI-AHCI: 8 makale).
} 
kaynakçasındaki referans sayısı da hem atıf sayısını artırmakta hem de hiç atıf almayan makale sayısını azaltmaktadır.

Makalelerin özlerindeki sözcük sayısı pozitif atıf sayısını artırmaktadır. Makalelerin yazar sayısı ile başlıklarındaki sözcük sayısının hiç atıf almayan makale sayısını azaltmadaki etkisi ihmal edilebilir düzeydedir.

Yabancı ülkelerle işbirliği yapılarak yayımlanan makaleler yaklaşık \%25 daha fazla atıf almakta, işbirliği yapılan kurum sayısı arttıkça atıf sayısı da kurum başına ortalama \%7 artmaktadır. Sanat ve insan bilimleri dergilerinde yayımlanan ve AHCI'de dizinlenen makaleler SCI'de dizinlenen fen bilimleri makalelerinden \%91 oranında daha az atıf almaktadır. Makalelere verilen desteğin (UBYT ve diğer destekler) ve makalenin açık erişim olarak yayımlanmasının pozitif atıf sayısının artmasında ya da hiç atıf almayan makale sayılarının azalmasında herhangi bir etkisi yoktur. İşbirliği ve dizinleme düzeyi değişkenlerin hiç atıf almayan makale sayılarının azalmasında herhangi bir etkisi yoktur.

$\mathrm{Bu}$ çalışma çok sayıda değişkeni test ederek TR adresli makalelerin atıf sayısının artmasında ve hiç atıf almayan makale sayısının azalmasında rol oynayan ortak faktörleri saptamaya yönelik olarak yapılan ilk çalışmalardan birisidir. Ancak bu çalışmanın en önemli sınırlılığı test edilen atıf sayısı, dergi etki faktörü, ortak yazar sayısı, işbirliği örüntüleri gibi değişkenlerin bilimsel disiplinlere göre farklılıklar göstermesidir (Fronzetti Colladon, D’Angelo ve Gloor, 2020, s. 363; Liu ve Fang, 2020). Yukarıda da görüldüğü gibi belli disiplinlerde ya da daha spesifik alanlarda atıf sayısını etkileyen faktörler bu araştırmada elde edilen faktörlerle tam olarak örtüşmeyebilir. Bu bakımdan farklı disiplinlerde TR adresli makalelerin atıf sayısını artıran spesifik faktörleri saptamaya yönelik araştırmalar yapılması gerekmektedir. Daha da önemlisi, TR adresli makalelerin ilgili bilim disiplinlerinin entellektüel içeriğine ve kavramsal yapısına katkısı çeşitli teknikler (yapısal değişim yaklaşımı, sosyal ağ analizi, anlamsal analiz vd.) kullanılarak incelenmelidir.

\section{Sonuç}

Araştırma sonuçlarına göre 19 bağımsız değişkenden sadece birkaç tanesi Türkiye adresli makalelerin atıf sayısını önemli ölçüde etkilemektedir. Dergilerin beş yıllık etki faktörü ve çeyrekliği ile makalelerdeki referans sayısı bunlardan en önemlileridir. Beş yıllık etki faktörü yüksek ve Q1 dergilerinde yayımlanan Türkiye adresli makaleler daha fazla atıf almaktadır. Bu tür dergilerde yayımlanan makaleler hiç atıf almama (sıfır atıf) engelini de daha kolay aşmaktadır. Bunun yanı sıra, yabancı ülkelerle ve kurumlarla işbirliği yapılarak yayımlanan ortak yazarlı makalelerin ortalama atıf sayıları daha yüksektir. Birden fazla konu altında listelenen ve SCI'de dizinlenen fen bilimleri makaleleri daha fazla atıf almaktadır. Makalelerin ortak yazar sayısı hiç atıf almama engelini aşmayı biraz kolaylaştırmaktadır.

Kanımızca bu bulgular Türkiye'nin uluslararası dergilerde yayımlanan makalelerin atıf etkisini artırabilmesi açısından önemli ipuçları içermektedir. Türkiye'de akademik atama ve yükseltmelerde ve TÜBİTAK UBYT Programında uzun süredir uygulanan ve son beş yıldır akademik teşvik ödeneğini de içerecek şekilde genişletilen "indeksli” dergilerde yayımlanan her makaleyi ödüllendirme stratejisinin doğru olmadığı bir kez daha ortaya çıkmıştır. Türkiye 
adresli makalelerin yaklaşık \%60'ını oluşturan Q3 ve Q4 dergilerinde ve çeyreklik değeri hesaplanmayan dergilerde yayımlanan makalelerin atıf etkisi Q1 ve Q2 dergilerinde yayımlanan makalelerinkinin üçte birinden daha düşüktür. Uluslararası işbirliği ile yayımlanan ortak yazarlı makalelerin atıf etkisi diğer makalelerinkinden yaklaşık bir kat daha yüksektir. UBYT desteği verilen makalelerin atıf etkisi destek verilmeyenlerinkinden nispeten daha düşüktür.

Bu sonuçlar Türkiye'de atama-yükseltme ve akademik teşvik politikalarının ivedilikle gözden geçirilmesi gerektiğini göstermektedir. $\mathrm{Bu}$ politikalar gözden geçirilirken ödüllendirilecek yayınların (ve dolayısıyla araştırmacıların) saptanmasında daha seçici davranılması yönünde değişiklikler yapılması gerekmektedir. Atıf etkisi nispeten sınırlı dergilerde yayın yapılmasını özendirmemek hatta bunun önüne geçmek için caydırıcı politikalar geliştirilmesine ihtiyaç vardır. Türkiye'nin en öncelikli konularından birisi bir an önce nicelik yerine niteliği temel ölçüt olarak alan, sadece bu ölçütü sağlayan araştırmaları özendiren ve destekleyen bir araştırma değerlendirme politikası geliştirmek olmalıdır.

\section{Teşekkür}

UBYT Programı ödeme verilerini sağlayan TÜBİTAK ULAKBİM Müdürü M. Mirat Satoğlu'ya teşekkür ederiz.

\section{Kaynakça}

Akçiğit, U. ve Özcan-Tok, E. (2020). Türkiye bilim raporu. TÜBA. http://www.tuba.gov.tr/tr/yayinlar/suresiz-yayinlar/raporlar/turkiye-bilim-raporu

Al, U. (2012). Avrupa Birliği ülkeleri ve Türkiye'nin yayın ve atıf performansı. bilig, 62, 1-20. http://bilig.yesevi.edu.tr/yonetim/icerik/makaleler/1208-published.pdf

Albarrán, P., Perianes-Rodrígues, A. ve Ruiz-Castillo, J. (2015). Differences in citation impact across countries. Journal of the Association for Information Science and Technology, 66(3), 512-525.

Allik, J., Lauk, K. ve Realo, A. (2020). Factors predicting the scientific wealth of nations. CrossCultural Research, 54(4), 364-397. https://doi.org/10.1177/1069397120910982

Article Influence. (2021). Clarivate: InCites help. https://incites.help.clarivate.com/Content/IndicatorsHandbook/ih-article-influence.htm

Baydemir, M. B. (2014). Lojistik regresyon analizi üzerine bir inceleme [Yayımlanmamış yüksek lisans tezi]. İnönü Üniversitesi. http://abakus.inonu.edu.tr/xmlui/bitstream/handle/11616/5650/Tez\%20Dosyas\%C4\%B1.pdf?se quence $=1 \&$ is Allowed $=\mathrm{y}$

Bornmann, L. ve Daniel, H. (2008). What do citation counts measure? A review of studies on citing behavior. Journal of Documentation, 64(1), 45-80. https://doi.org/10.1108/00220410810844150

Bornmann, L., Wagner, C. ve Leydesdorff, L. (2018). The geography of references in elite articles: Which countries contribute to the archives of knowledge? PLOS ONE, 13(3), e0194805. https://doi.org/10.1371/journal.pone.0194805

CiTO. (2018, 16 Şubat). The citation typing ontology. https://sparontologies.github.io/cito/current/cito.html

Chen, C. (2012). Predictive effects of structural variation on citation counts. Journal of the American Society for Information Science and Technology, 63(3), 431-449. https://doi.org/10.1002/asi.21694 
Confraria, H., Godinho, M. M. ve Wang, L. (2017). Determinants of citation impact: A comparative analysis of the Global South versus the Global North. Research Evaluation, 46(1), 265-279. http://dx.doi.org/10.1016/j.respol.2016.11.004

Desjardins, C. D. (2016). Modeling zero-inflated and overdispersed count data: An empirical study of school suspensions, The Journal of Experimental Education, 84(3), 449-472. https://doi.org/10.1080/00220973.2015.1054334

Didegah, F. ve Thelwall, M. (2013a). Which factors help authors produce the highest impact research? Collaboration, journal and document properties. Journal of Informetrics, 7(4), 861-873. http://dx.doi.org/10.1016/j.joi.2013.08.006

Didegah, F. ve Thelwall, M. (2013b). Determinants of research citation impact in nanoscience and nanotechnology. Journal of the American Society for Information Science and Technology, 64(5), 1055-1064. https://doi.org/10.1002/asi.22806

Dinarcan, G. N. (2018). Sayma verisi için regresyon modelleri ve bir uygulama [Yayımlanmamış yüksek lisans tezi]. Hacettepe Üniversitesi. http://www.openaccess.hacettepe.edu.tr:8080/xmlui/bitstream/handle/11655/4613/10195911.pdf ?sequence $=4 \&$ is Allowed $=\mathrm{y}$

Fischer, I. ve Steiger, H-J. (2018). Dynamics of Journal Impact Factors and limits to their inflation. Journal of Scholarly Publishing, 50(1), 26-36. https://doi.org/10.3138/jsp.50.1.06

Fronzetti Colladon, A., D'Angelo, C. A. ve Gloor, P. A. (2020). Predicting the future success of scientific publications through social network and semantic analysis. Scientometrics, 124, 357377. https://doi.org/10.1007/s11192-020-03479-5

Good, B., Vermeulen, N., Tiefenthaler, B. ve Arnold, E. (2015). Counting quality? The Czech performance-based research funding system. Research Evaluation, 24(2), 91-105. https://doi.org/10.1093/reseval/rvu035

Gök, A., Rigby, J. ve Shapira, P. (2016). The impact of research funding on scientific outputs: Evidence from six smaller European countries. Journal of the Association for Information Science and Technology, 67(3), 715-730. https://doi.org/10.1002/asi.23406

Hicks, D., Wouters, P., Waltman, L., de Rijcke, S. ve Rafols, I. (2015). Bibliometrics: The Leiden Manifesto for research metrics. Nature, 520(7548), 429-431. https://doi.org/10.1038/520429a

Jackman, S., Tahk, A., Zeileis, A., Maimone, C., Fearon, J. ve Meers, Z. (2020). Package 'pscl'. https://cran.r-project.org/web/packages/pscl/pscl.pdf

Kamalski, J., Huggett, S., Kalinaki, E., Lan, G., Lau, G., Pan, L. ve Scheerooren, S. (2017). World of Research 2015: Revealing patterns and archetypes in scientific research. http://dlibra.umcs.lublin.pl/dlibra/docmetadata?id=26567\&from=pubindex\&dirids=12\&lp=478

Kleiber, C. ve Zeileis, A. (2016). Visualizing count data regressions using rootograms, The American Statistician, 70(3), 296-303. https://doi.org/10.1080/00031305.2016.1173590

Kostoff, R. N. (1998). The use and misuse of citation analysis in research evaluation. Scientometrics, 43(1), 27-43. https://doi.org/10.1007/BF02458392

Kostoff, R. N. (2007). The difference between highly and poorly cited medical articles in the journal Lancet. Scientometrics, 72, 513-520. https://doi.org/10.1007/s11192-007-1573-7

Larivière, V., Kiermer, V., MacCallum, C. J., McNutt, M., Patterson, M., Pulverer, B., Swaminarhan, S., Taylor, S. ve Curry, S. (2016). A simple proposal for the publication of journal citation distributions. https://doi.org/10.1101/062109

Leydesdorff, L., Bornmann, L. ve Wagner, C. S. (2019). The relative influences of government funding and international collaboration on citation impact. Journal of the Association for Information Science and Technology, 70(2), 198-201. https://doi.org/10.1002/asi.24109 
Lindsey, D. (1989). Using citation counts as a measure of quality in science measuring what's measurable rather than what's valid. Scientometrics, 15(3-4), 189-203. https://doi.org/10.1007/BF02017198

Liu, F., Guo, W. ve Zuo, C. (2018). High impact factor journals have more publications than expected. Current Science, 114(5), 955-956. https://doi.org/10.18520/cs\%2Fv114\%2Fi05\%2F955-956

Liu, X. Z. ve Fang, H. (2020). A comparison among citation-based journal indicators and their relative changes with time. Journal of Informetrics, 14(1), 1-17. https://doi.org/10.1016/j.joi.2020.101007

MacRoberts, M. H. ve MacRoberts, B. R. (1989). Problems of citation analysis: A critical review. Journal of the American Society for Information Science, 40(5), 342-349. https://doi.org/10.1002/(SICI)1097-4571(198909)40:5<342::AID-ASI7>3.0.CO;2-U

MacRoberts, M. H. ve MacRoberts, B. R. (1996). Problems of citation analysis. Scientometrics, 36(3), 435-444. https://doi.org/10.1007/BF02129604

MacRoberts, M. H. ve MacRoberts, B. R. (2018). The mismeasure of science: Citation analysis. Journal of the Association for Information Science and Technology, 69(3), 474-482. https://doi.org/10.1002/asi.23970

Merton, R. K. (1968). The Matthew effect in science. Science, 159(3810), 56-63. https://doi.org/10.1126/science.159.3810.56

Miranda, R. ve Garcia-Carpintero, E. (2019). Comparison of the share of documents and citations from different quartile journals in 25 research areas. Scientometrics, 121(1), 479-501. https://doi.org/10.1007/s11192-019-03210-z

Muller, J. Z. (2019). Sayıların diktatörlüğ̈̈: Başarlyı rakamlarla ölçme saplantısı ve çözüm yolları (A. Kamacioğlu, Çev.). The Kitap.

Nicolaisen, J. ve Frandsen, T. F. (2019). Zero impact: A large-scale study of uncitedness. Scientometrics, 119(2), 1227-1254. https://doi.org/10.1007/s11192-019-03064-5

Onodera, N. ve Yoshikane, F. (2015). Factors affecting citation rates of research articles. Journal of the Association for Information Science and Technology, 66(4), 739-764. https://doi.org/10.1002/asi.23209

Orbay, K., Miranda, R. ve Orbay, M. (2020). Building journal impact factor quartile into the assessment of academic performance: A case study. Participatory Educational Research (PER), 7(2), 1-13. https://doi.org/10.17275/per.20.26.7.2

Orbay, M., Karamustafaoğlu, O. ve Miranda, R. (2021). Analysis of the journal impact factor and related bibliometric indicators in education and educational research category. Education for Information, 37(3), 315-336. https://doi.org/10.3233/EFI-200442

Pranckute, R. (2021). Web of Science (WoS) and Scopus: The titans of bibliographic information in today's academic world. Publications, 9(1), 1-59. https://doi.org/10.3390/publications9010012

San Francisco Declaration on Research Assessment. (2012, 16 Aral1k). What is DORA? http://ascb.org/dora

Satoğlu, E. B., Balkış, G. ve Damar, H. (2021). TÜBİTAK araştırma geliştirme ve proje desteklerinin akademik araştırma faaliyetlerine olan etkisi. Yüksekögretim ve Bilim Dergisi, 11(1), 83-91. https://doi.org/10.5961/jhes.2021.431

Seglen, P. O. (1997). Why the impact factor of journals should not be used for evaluating research. British Medical Journal, 314(7079), 498-502. https://doi.org/10.1136/bmj.314.7079.497

Sivertsen, G. (2016). Patterns of internationalization and criteria for research assessment in social sciences and humanities. Scientometrics, 107(2), 357-368. https://doi.org/10.1007/s11192-016$1845-1$ 
Sivertsen, G. (2019). Understanding and evaluating research and scholarly publishing in the Social Sciences and Humanities (SSH). Data and Information Management, 3(2), 61-71. https://doi.org/10.2478/dim-2019-0008

Tonta, Y. (2017). TÜBİTAK Türkiye Adresli Uluslararası Bilimsel Yayınları Teşvik (UBYT) programinın değerlendirilmesi. TÜBİTAK ULAKBIM. http://yunus.hacettepe.edu.tr/ tonta/yayinlar/tonta-tubitak-ubyt-programinindegerlendirilmesi.pdf

Tonta, Y. (2018). Does monetary support increase the number of scientific papers? An interrupted time series analysis. Journal of Data and Information Science, 3(1), 19-39. https://doi.org/10.2478/jdis-2018-0002

Tonta, Y. ve Akbulut, M. (2020). Does monetary support increase citation impact of scholarly papers? Scientometrics, 125(2), 1617-1641. https://doi.org/10.1007/s11192-020-03688-y

Traag, V. A. (2021). Inferring the causal effect of journals on citations. Quantitative Science Studies, 2(2), 496-504. https://doi.org/10.1162/qss_a_00128

Tüzen, M. F. ve Erbaş, S. (2017). A comparison of count data models with an application to daily cigarette consumption of young persons. Communications in Statistics - Theory and Methods, 47(23), 5825-5844. https://doi.org/10.1080/03610926.2017.1402050

Yan, E., Wu, C. ve Song, M. (2018). The funding factor: A cross-disciplinary examination of the association between research funding and citation impact. Scientometrics, 115, 369-384. https://doi.org/10.1007/s11192-017-2583-8

Yurtsever, E., Gülgöz, S., Yedekçioğlu, Ö. A. ve Tonta, M. (2001). Sosyal Bilimler Atıf Dizini'nde (SSCI) Türkiye: 1970-1999. Türkiye Bilimler Akademisi.

Yurtsever, E., Gülgöz, S., Yedekçioğlu, Ö. A. ve Tonta, M. (2002). Sağllk bilimleri, mühendislik ve temel bilimlerde Türkiye'nin uluslararası atıf dizinindeki yeri 1973-1999. Türkiye Bilimler Akademisi.

Zeileis, A., Kleiber, C. ve Jackman, S. (2008). Regression models for count data in R. Journal of Statistical Software, 27(8), 1-25. https://doi.org/10.18637/jss.v027.i08 